\title{
The impact of the 1783-1784 AD Laki eruption on global aerosol formation processes and cloud condensation nuclei
}

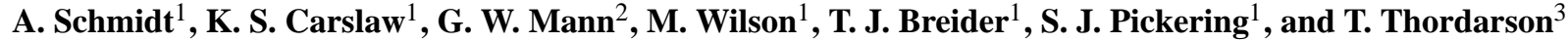 \\ ${ }^{1}$ School of Earth and Environment, University of Leeds, LS2 9JT, UK \\ ${ }^{2}$ NCAS, University of Leeds, LS2 9JT, UK \\ ${ }^{3}$ School of Geosciences, Grant Institute, University of Edinburgh, Edinburgh, UK
}

Received: 9 December 2009 - Published in Atmos. Chem. Phys. Discuss.: 5 February 2010

Revised: 14 June 2010 - Accepted: 17 June 2010 - Published: 5 July 2010

\begin{abstract}
The 1783-1784 AD Laki flood lava eruption commenced on 8 June 1783 and released $122 \mathrm{Tg}$ of sulphur dioxide gas over the course of 8 months into the upper troposphere and lower stratosphere above Iceland. Previous studies have examined the impact of the Laki eruption on sulphate aerosol and climate using general circulation models. Here, we study the impact on aerosol microphysical processes, including the nucleation of new particles and their growth to cloud condensation nuclei (CCN) using a comprehensive Global Model of Aerosol Processes (GLOMAP). Total particle concentrations in the free troposphere increase by a factor $\sim 16$ over large parts of the Northern Hemisphere in the 3 months following the onset of the eruption. Particle concentrations in the boundary layer increase by a factor 2 to 5 in regions as far away as North America, the Middle East and Asia due to long-range transport of nucleated particles. $\mathrm{CCN}$ concentrations (at $0.22 \%$ supersaturation) increase by a factor 65 in the upper troposphere with maximum changes in 3-month zonal mean concentrations of $\sim 1400 \mathrm{~cm}^{-3}$ at high northern latitudes. 3-month zonal mean $\mathrm{CCN}$ concentrations in the boundary layer at the latitude of the eruption increase by up to a factor 26 , and averaged over the Northern Hemisphere, the eruption caused a factor 4 increase in $\mathrm{CCN}$ concentrations at low-level cloud altitude. The simulations show that the Laki eruption would have completely dominated as a source of CCN in the pre-industrial atmosphere. The model also suggests an impact of the eruption in the Southern Hemisphere, where CCN concentrations are increased by up to a factor 1.4 at $20^{\circ} \mathrm{S}$. Our model simulations suggest that the impact of an equivalent wintertime eruption on upper tropo-
\end{abstract}

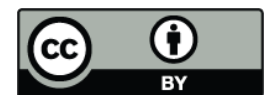

Correspondence to: A. Schmidt (a.schmidt@see.leeds.ac.uk) spheric CCN concentrations is only about one-third of that of a summertime eruption. The simulations show that the microphysical processes leading to the growth of particles to $\mathrm{CCN}$ sizes are fundamentally different after an eruption when compared to the unperturbed atmosphere, underlining the importance of using a fully coupled microphysics model when studying long-lasting, high-latitude eruptions.

\section{Introduction}

The 1783-1784 AD Laki eruption commenced on 8 June 1783 and emitted $\sim 122 \mathrm{Tg}$ of sulphur dioxide $\left(\mathrm{SO}_{2}\right)$ into the upper troposphere/lower stratosphere above Iceland. The eruption lasted 8 months and represents one of the largest flood lava eruptions in recent history, causing widespread atmospheric pollution and environmental devastation (Thordarson, 1995; Thordarson et al., 1996; Thordarson and Self, 2003). Thordarson and Self (2003) presented a comprehensive review of the course of the Laki eruption, including a detailed volatile release budget and a contemporary account of the atmospheric and environmental consequences observed for around two years following the eruption. This comprehensive review has enabled the impacts of the Laki eruption to be studied using numerical models (Stevenson et al., 2003; Highwood and Stevenson, 2003; Chenet et al., 2005; Oman et al., 2006a,b). Stevenson et al. (2003) studied the atmospheric impact of the eruption using the STOCHEM chemistry transport model (CTM) in the Hadley Centre's Unified Model General Circulation Model (GCM) using the Laki $\mathrm{SO}_{2}$ emissions dataset from Thordarson and Self (2003). Stevenson et al. (2003) estimated that the eruption produced a total of $17-22 \mathrm{Tg}(\mathrm{S})$ of sulphuric acid aerosol (=71 to $92 \mathrm{Tg}$

Published by Copernicus Publications on behalf of the European Geosciences Union. 
of volcanic sulphate aerosol assuming a composition of $75 \%$ $\mathrm{H}_{2} \mathrm{SO}_{4}$ and $25 \% \mathrm{H}_{2} \mathrm{O}$ ). In a follow-up study, Highwood and Stevenson (2003) used the Reading Intermediate GCM to calculate an annual mean Northern Hemisphere temperature anomaly of $0.21 \mathrm{~K}$ based on the aerosol fields obtained by Stevenson et al. (2003). Chenet et al. (2005) modelled the spatial and temporal distribution of $200 \mathrm{Mt}$ of sulphate aerosol (a theoretical value of the total sulphate aerosol yield as derived from Stothers, 1996 and Thordarson and Self, 2003) using the LMDZT-INCA GCM and found good agreement with the observations presented in Thordarson and Self (2003). More recently, Oman et al. (2006a) used the dataset of Thordarson and Self (2003) in the Goddard Institute for Space Studies (GISS) modelE GCM (Schmidt et al., 2006) coupled to a sulphur chemistry scheme (Koch et al., 2006) to simulate the chemical transformation of $\sim 122 \mathrm{Tg}$ of $\mathrm{SO}_{2}$ and the subsequent sulphate aerosol dispersal. Oman et al. (2006a) estimated that the Laki eruption yielded between 163 and $166 \mathrm{Tg}$ of total volcanic sulphate aerosol (assuming a composition of $75 \% \mathrm{H}_{2} \mathrm{SO}_{4}$ and $25 \% \mathrm{H}_{2} \mathrm{O}$ ) and calculated a substantial radiative perturbation with a peak top-ofatmosphere net radiative forcing of $-27 \mathrm{~W} \mathrm{~m}^{-2}$ in August. Moreover, Oman et al. (2006b) found a weakening of the Indian and Asian monsoon systems as a consequence of highlatitude volcanism such as Laki. This finding is supported by the earlier modelling study of Graf (1992) in which a reduced incoming solar radiation north of $50^{\circ} \mathrm{N}$ represented the aftermath of a strong volcanic eruption. Gauci et al. (2008) found a significant suppression of the northern wetland $\mathrm{CH}_{4}$ source due to the presence and deposition of excessive amounts of volcanic sulphate aerosol during the Laki eruption. Moreover, increased mortality rates not only in Iceland but also in France, Britain and elsewhere in Europe (e.g., Grattan et al., 2003; Grattan, 2005; Courtillot, 2005) are thought to be a direct consequence of the 1783-1784 AD Laki eruption, implying drastically increased pollution levels over Iceland and Europe in the summer of 1783.

Previous Laki studies were conducted using GCMs with varying degrees of realism of the emission scenario and the treatment of the aerosol processes. The Stevenson et al. (2003) study used various emission scenarios in terms of injection height of $\mathrm{SO}_{2}$, although the scenarios are likely not to be representative of the assessed course of the Laki eruption (Thordarson et al., 1996; Thordarson and Self, 2003). Chenet et al. (2005) injected 20\% of the sulphate aerosol as smoothed monthly means at an altitude of $5 \mathrm{~km}$ and $80 \%$ at an altitude of $10 \mathrm{~km}$. The Oman et al. (2006a) study is the most sophisticated in terms of an accurate representation of the eruption as gathered from the assessment of Thordarson and Self (2003).

The emphasis of our study is on the effect of the emitted $\mathrm{SO}_{2}$ on aerosol microphysical processes and changes in particle concentrations. In contrast to previous studies, we use a dedicated global aerosol microphysics model to simulate the driving aerosol processes, such as nucleation, conden- sation and coagulation, as well as the subsequent evolution of the aerosol size distribution, thereby allowing us to assess the impact on the global budget of total particle number concentration and cloud condensation nuclei (CCN). In addition, we simulate a hypothetical Laki scenario commencing in December (rather than June) in order to provide insights into the impact of the season of such an eruption on the above-mentioned processes. Several studies (Graf et al., 1997; Mather et al., 2003, 2004; Gassó, 2008) showed that a detailed understanding of volcanically induced $\mathrm{CCN}$ is vital for assessing the potential ability of volcanic eruptions to alter cloud microphysical processes. Moreover, Timmreck et al. (2009) suggested that it is crucial to use fully coupled chemistry and microphysics models in order to simulate the volcanic aerosol size distribution and correctly constrain the effect of very large volcanic eruptions on temperature, aerosol optical depth, and subsequently the environmental impact.

\section{Model and experiment description}

\subsection{The GLOMAP-mode model}

We use the global aerosol microphysics model GLOMAPmode (Mann et al., 2010) implemented in the global 3-D off-line chemical transport model TOMCAT (Chipperfield, 2006). The simulations were conducted using a horizontal resolution of $2.8^{\circ} \times 2.8^{\circ}$ and 31 hybrid $\sigma-p$ levels extending from the surface to $10 \mathrm{hPa}$. The model is forced by reanalysed 2003 meteorology and large-scale atmospheric transport fields specified from the European Centre for MediumRange Weather Forecasts (ECMWF) at 6-h intervals. We chose to use meteorological fields from the year 2003 as synoptic weather maps of the summer 1783 AD reveal unusually hot July temperatures in Western Europe and the presence of persistent anticyclones over Central Europe (Thordarson and Self, 2003, and references therein). The year 2003 was characterised by similar meteorological features during the summer months. However, as we do not force the model using meteorological fields for the year $1783 \mathrm{AD}$, the simulations herein should be regarded as representing a "Lakistyle" eruption.

GLOMAP-mode represents the aerosol size distribution as log-normal modes with two moments of the distribution (particle number concentration and component mass concentrations) prognosed in each mode. For this study the runs were conducted using two internally mixed aerosol components, sulphate $\left(\mathrm{SO}_{4}\right)$ and sea salt. We used 4 particle modes: water-soluble nucleation, Aitken, accumulation and coarse modes. GLOMAP-mode treats microphysical processes such as binary homogeneous nucleation, hygroscopic growth, coagulation, condensation, cloud processing (oxidation of dissolved $\mathrm{SO}_{2}$ to $\mathrm{SO}_{4}$ in cloud droplets), as well as dry and wet deposition. Aqueous phase oxidation of $\mathrm{SO}_{2}$ to $\mathrm{SO}_{4}$ is 
assumed to occur in low-level clouds, which are specified in terms of monthly mean cloud top pressure and cloud fraction fields from the International Satellite Cloud Climatology Project (ISCCP). The sulphur chemistry scheme is based on Pham et al. (1995) and includes 7 species (DMS, DMSO, MSA, $\left.\mathrm{SO}_{2}, \mathrm{H}_{2} \mathrm{SO}_{4}, \mathrm{COS}, \mathrm{CS}_{2}\right)$. The sulphur chemistry is coupled to the full background chemistry $\left(\mathrm{O}_{\mathrm{x}}-\mathrm{NO}_{\mathrm{y}}-\mathrm{HO}_{\mathrm{x}}-\mathrm{C}_{1}-\right.$ $\mathrm{C}_{3}$, NMHCs, isoprene) in TOMCAT, allowing for interactions between the sulphur species and oxidants (Breider et al., 2010).

Mann et al. (2010) present a detailed description of GLOMAP-mode including the aerosol scheme and its evaluation against observations showing that the model is capable of simulating realistic present-day aerosol mass concentrations, number concentrations, size distributions, and CCN concentrations in both marine and continental locations.

\subsection{Experimental design and emissions}

We simulated the impact of the eruption in a pre-industrial setting (i.e. in the absence of anthropogenic emissions) with the following natural emissions: $13.3 \mathrm{Tg}(\mathrm{S}) \mathrm{a}^{-1}$ volcanic $\mathrm{SO}_{2}$ using the recommendations by Dentener et al. (2006) which are based on datasets by Andres and Kasgnoc (1998) and Halmer et al. (2002); 17.7 Tg (S) $\mathrm{a}^{-1}$ oceanic dimethylsulfide (DMS) (Kettle and Andreae, 2000) assuming a seaair transfer velocity parameterisation of Nightingale et al. (2000). Sea spray emissions were driven by wind speeds updated every $6 \mathrm{~h}$ using the emissions parameterisation of Gong (2003). Our simulations do not include aerosol formation due to biomass burning as its magnitude is highly uncertain for pre-industrial times.

We conducted two Laki simulations: 1 ) a standard summer Laki scenario with the eruption beginning on 8 June (hereafter referred to as L-s) reproducing the actual eruption; 2) a hypothetical winter Laki scenario commencing on 8 December (hereafter referred to as L-w). We used the dataset of Thordarson and Self (2003) to define the magnitude, altitude and timing of the release of $\mathrm{SO}_{2}$ into the atmosphere (Fig. 1). It should be noted from Fig. 1 that the Laki eruption was most vigorous during the first 1.5 months. To represent emissions from the Laki vent system, a total of $94.3 \mathrm{Tg}$ $\mathrm{SO}_{2}$ was emitted into model grid boxes between 9 and $13 \mathrm{~km}$ above Iceland $\left(17^{\circ} \mathrm{W}, 64^{\circ} \mathrm{N}\right)$ as 10 discrete $\mathrm{SO}_{2}$ mass loadings (as suggested by Thordarson and Self, 2003) each injected within one $6 \mathrm{~h}$ period. In addition, a total of $27.6 \mathrm{Tg}$ $\mathrm{SO}_{2}$ was continuously emitted into grid boxes between the surface and $1 \mathrm{~km}$, representing passive degassing from the Laki lava flows. Both, $\mathrm{L}-\mathrm{s}$ and $\mathrm{L}$-w use the same $\mathrm{SO}_{2}$ mass loadings and the same temporal development, but L-s commences on 8 June and L-w on 8 December. We note that our representation of the $\mathrm{SO}_{2}$ mass loadings is identical to that used by Oman et al. (2006a) but differs from that of Stevenson et al. (2003) in that we used discrete $\mathrm{SO}_{2}$ mass loadings to represent degassing from the vent system instead of

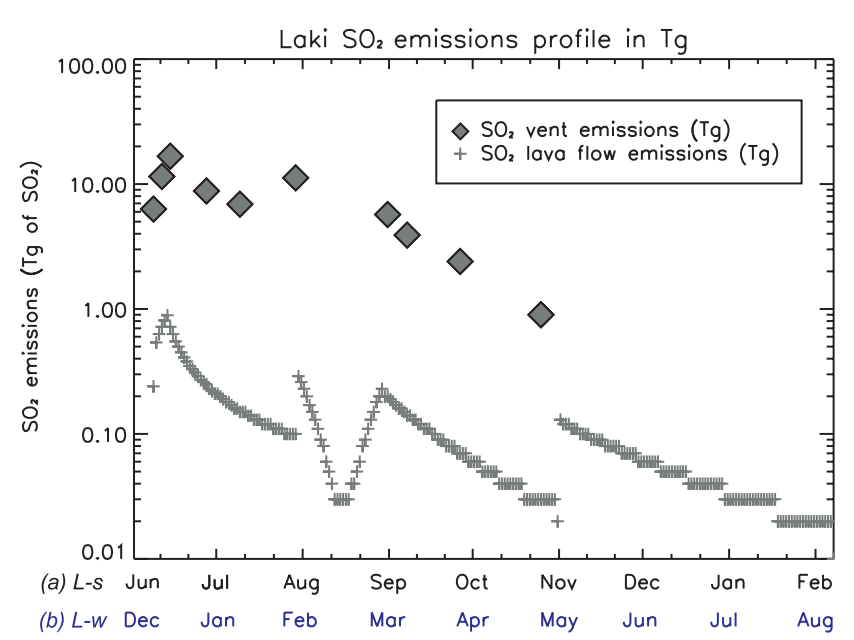

Fig. 1. Daily gas-phase $\mathrm{SO}_{2}$ mass-loading in $\mathrm{Tg}$ for (a) L-s simulation commencing on the 8 June and (b) for the hypothetical L-w simulation commencing on 8 December. Diamonds represent ten $\mathrm{SO}_{2}$ mass loadings from the Laki vent system injected into the upper troposphere/lower stratosphere (i.e. between 9 and $13 \mathrm{~km}$ ) and crosses represent daily $\mathrm{SO}_{2}$ emissions from the Laki lava flows released into the boundary layer (i.e. between surface and $1 \mathrm{~km}$ ). $\mathrm{SO}_{2}$ mass loadings and temporal resolution for $\mathrm{L}-\mathrm{s}$ are derived from Thordarson and Self (2003) with L-w employing the same mass loadings and relative temporal resolution but commencing on 8 December.

monthly mean $\mathrm{SO}_{2}$ emissions or daily $\mathrm{SO}_{2}$ emissions falling to $1 / \mathrm{e}$ of their initial value at the end of each eruption episode. We do not attempt to simulate the dispersal of volcanic ash injected into the atmosphere by the Laki eruption, nor do we account for heterogeneous formation of $\mathrm{H}_{2} \mathrm{SO}_{4}$ on ash particles which could potentially modify the aerosol size distribution due to condensation and coagulation, and scavenge sulphur (e.g., Turco et al., 1983). However, these limitations only apply as long as ash is present in the atmosphere - commonly a lifetime on the order of days is assumed for fine volcanic ash resulting in a rather localised and small longterm effect, as shown for stratospheric volcanic aerosol by Niemeier et al. (2009).

We compare our findings with previous modelling studies by Stevenson et al. (2003) and Oman et al. (2006a), and with records of $\mathrm{SO}_{4}$ deposition in Greenland (Clausen and Hammer, 1988; Mosley-Thompson et al., 2003) and Svalbard icecores (Kekonen et al., 2005).

\section{Results and discussion}

\section{1 $\mathrm{SO}_{2}$ and $\mathrm{SO}_{4}$ mixing ratios and burdens}

Figure 2 shows changes in zonal 3-month mean $\mathrm{SO}_{2}$ and $\mathrm{SO}_{4}$ aerosol mixing ratios for $\mathrm{L}-\mathrm{s}$ and $\mathrm{L}-\mathrm{w}$. $\mathrm{SO}_{2}$ mixing ratios increase by $\sim 140 \mathrm{ppbv}$ and $\sim 96 \mathrm{ppbv}$ at altitudes between 10 and $12 \mathrm{~km}$ for L-s and L-w, respectively. For both 
a)

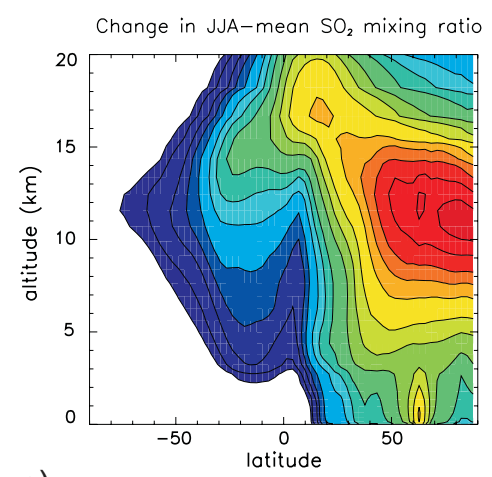

C)

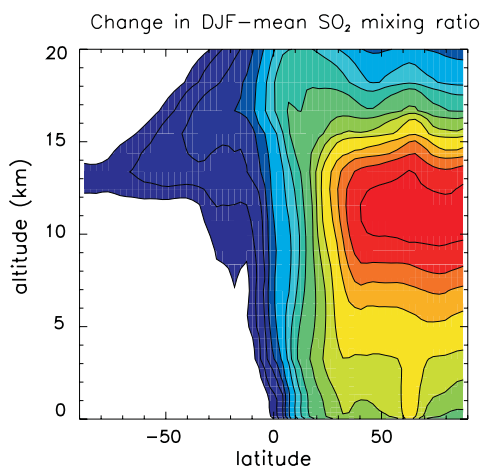

b)

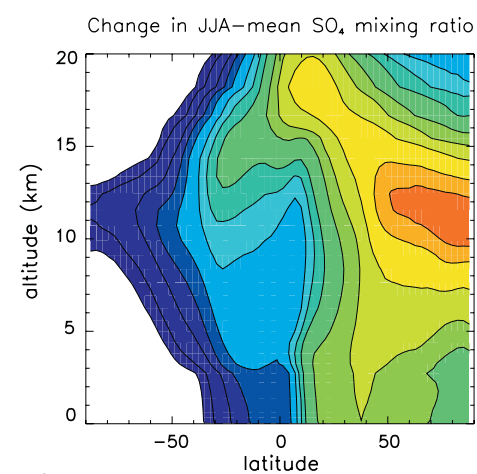

d)

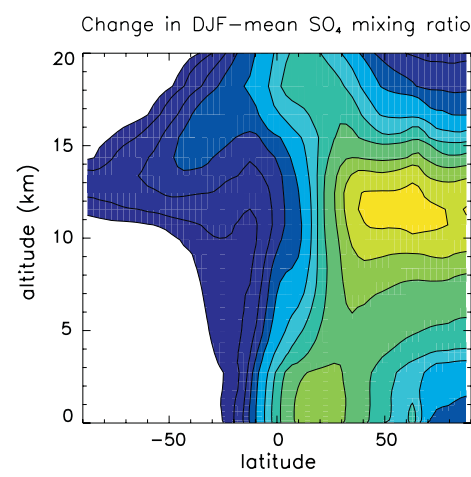

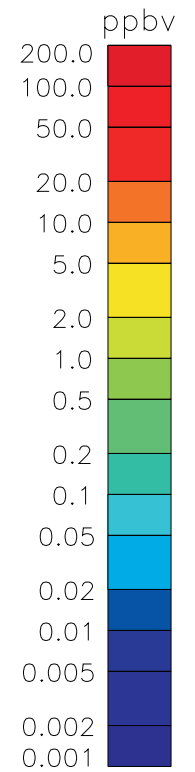

0.001

Fig. 2. Simulated changes (i.e. perturbed minus unperturbed) in zonal 3-month mean $\mathrm{SO}_{2}$ and $\mathrm{SO}_{4}$ aerosol mixing ratios in parts per billion by volume (ppbv) for L-s (a and $\mathbf{b})$ and L-w (c and $\mathbf{d})$. JJA=June-July-August; DJF=December-January-February.

eruption scenarios elevated $\mathrm{SO}_{2}$ mixing ratios of $\sim 5 \mathrm{ppbv}$ are simulated in the boundary layer close to the eruption site due to continuous emission of $\mathrm{SO}_{2}$ from the lava flows. In comparison, mean $\mathrm{SO}_{2}$ mixing ratios of $\sim 1$ ppbv are modelled in anthropogenically polluted regions over Europe using GLOMAP (Spracklen et al., 2005a). Thus the 1783$1784 \mathrm{AD}$ Laki eruption would have been a strong pollutant in the pre-industrial atmosphere. Zonal 3-month mean $\mathrm{SO}_{4}$ aerosol mixing ratios reach $17.8 \mathrm{ppbv}$ during L-s and 2.9 ppbv during L-w at altitudes from 10 to $12 \mathrm{~km}$. $\mathrm{SO}_{4}$ mixing ratios in the boundary layer and middle troposphere from $30^{\circ} \mathrm{N}$ to $75^{\circ} \mathrm{N}$ are a factor 4.4 higher for L-s than for L-w. $\mathrm{SO}_{4}$ mixing ratios show a much greater difference than $\mathrm{SO}_{2}$ mixing ratios when comparing $\mathrm{L}-\mathrm{s}$ and $\mathrm{L}-\mathrm{w}$ due to a faster photochemical conversion of $\mathrm{SO}_{2}$ to $\mathrm{SO}_{4}$ during $\mathrm{L}$-s.

We note that a small fraction (up to $\sim 1$ ppbv) of both $\mathrm{SO}_{2}$ and $\mathrm{SO}_{4}$ is transported into the Southern Hemisphere ( $\mathrm{SH}$ ) via the tropical tropopause layer. From an atmospheric transport point of view, these results are consistent with Levine et al. $(2007,2008)$ who showed that the TOMCAT CTM is capable of realistically simulating the relatively fast transport of tracers along isentropic surfaces and the efficient mixing process between the tropical upper troposphere and the lower stratosphere. These findings differ from previous model studies (Chenet et al., 2005; Oman et al., 2006a), which showed that the impact of the Laki eruption tends to be confined to the Northern Hemisphere (NH). However, a recent compilation of historic observations (Trigo et al., 2009) supports a possible impact of the 1783-1784 AD Laki eruption in Brazil $\left(20^{\circ} \mathrm{S}\right)$. Also, Stevenson et al. (2003) stated that the impact of the Laki eruption is basically confined to the $\mathrm{NH}$, but mentioned the transport of a small amount of $\mathrm{SO}_{4}$ into the $\mathrm{SH}$. Our Laki simulations show that the descent of $\mathrm{SO}_{2}$ gas and $\mathrm{SO}_{4}$ aerosol into the $\mathrm{SH}$ troposphere starts during the second month after the onset of the eruption. Despite there being only relatively minor changes in mixing ratios, the additional $\mathrm{SO}_{2}$ gas and $\mathrm{SO}_{4}$ aerosol entrained into the $\mathrm{SH}$ will affect microphysical processes such as coagulation and direct growth of particles. We show in Sect. 3.5.2 that even small amounts of $\mathrm{SO}_{4}$ can have a substantial effect on $\mathrm{CCN}$, consistent with our previous study (Manktelow et al., 2009).

Figure 3 shows the global monthly mean atmospheric $\mathrm{SO}_{2}$ and $\mathrm{SO}_{4}$ burdens (i.e. the amount of $\mathrm{SO}_{2}$ and $\mathrm{SO}_{4}$ in the atmosphere at a given time), the ratio of $\mathrm{SO}_{2}$ to $\mathrm{SO}_{4}$ burden, and global monthly mean $\mathrm{SO}_{2}$ and $\mathrm{SO}_{4}$ residence times for L-s and L-w, respectively. The most obvious differences between the summer and winter simulations are the higher $\mathrm{SO}_{2}$ burden and the longer 3-month mean $\mathrm{SO}_{2}$ residence time of 34 days for $\mathrm{L}-\mathrm{w}$ compared to 24 days for $\mathrm{L}-\mathrm{s}$. This compares to typical $\mathrm{SO}_{2}$ residence times of $\sim 2$ days (e.g., Spracklen et 
a)

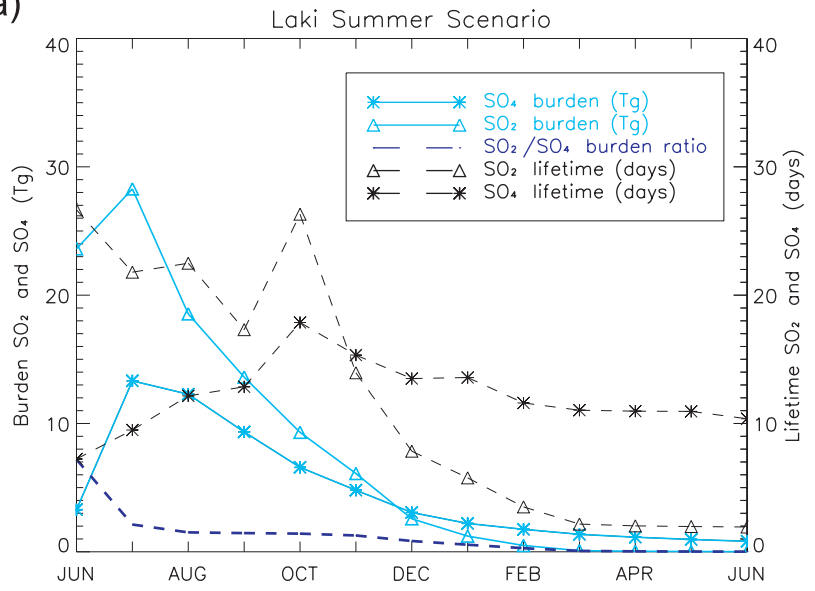

b)

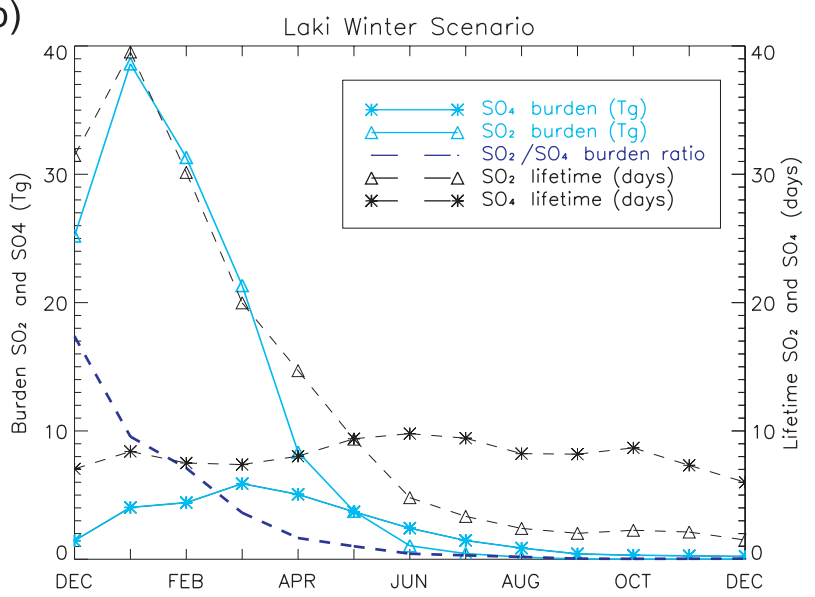

Fig. 3. Simulated global monthly mean $\mathrm{SO}_{2}$ burden (solid, light blue line with triangles) and $\mathrm{SO}_{4}$ burden (solid, light blue line with asterisks), $\mathrm{SO}_{2}$ to $\mathrm{SO}_{4}$ ratio (dashed dark blue line), and $\mathrm{SO}_{2}$ residence time (dashed black line with triangles) and $\mathrm{SO}_{4}$ aerosol residence time (dashed black line with asterisks) for L-s (a) and Lw (b), respectively.

al., 2005a) under current, anthropogenically polluted atmospheric conditions. The significant increase in $\mathrm{SO}_{2}$ residence times in the volcanically perturbed simulations is a result of the injection of $\mathrm{SO}_{2}$ well above the boundary layer where removal rates are low as well as suppression of the oxidants (see Sect. 3.2). The higher wintertime $\mathrm{SO}_{2}$ burden and residence time are a result of a less efficient oxidation of $\mathrm{SO}_{2}$ to $\mathrm{H}_{2} \mathrm{SO}_{4}$ vapour when compared to the summertime eruption.

Figure 4a shows the simulated global 12-month mean sulphur species budget for the unperturbed run and for L-s (as an absolute difference from the unperturbed run) and Fig. 4b compares the same budgets for L-w. For L-s the dry oxidation of $\mathrm{SO}_{2}$ by $\mathrm{OH}$ to form $\mathrm{SO}_{4}$ dominates the in-cloud oxidation pathway. In comparison, Manktelow et al. (2007) showed that in-cloud oxidation is the dominant $\mathrm{SO}_{4}$ formation process under present day atmospheric conditions. The reason for this difference is that most of the volcanic $\mathrm{SO}_{2}$ is injected into the cloud-free mid-troposphere. For L-w, however, in-cloud oxidation and dry oxidation are approximately equally important pathways to form $\mathrm{SO}_{4}$. The different $\mathrm{SO}_{4}$ production pathways significantly affect the aerosol microphysical processes (see Sect. 3.4 for more details). Production of $\mathrm{H}_{2} \mathrm{SO}_{4}$ vapour (and subsequently particulate $\mathrm{SO}_{4}$ ) via gas-phase oxidation of $\mathrm{SO}_{2}$ by $\mathrm{OH}$ is a factor $\sim 1.6$ lower in $\mathrm{L}-\mathrm{w}$ than in L-s due to slower photochemistry. This summerwinter difference affects the timing of the peak $\mathrm{SO}_{4}$ burden relative to the onset of the simulated eruption. In L-s, the peak $\mathrm{SO}_{4}$ burden occurs in the month following the eruption, whereas the peak in L-w occurs almost 4 months after the onset of the eruption during spring. As a consequence $\mathrm{SO}_{2}$ burdens and $\mathrm{SO}_{2}$ removal rates during $\mathrm{L}-\mathrm{w}$ remain higher than during L-s throughout the first 5 months. In L-w 32\% of the $\mathrm{SO}_{2}$ is removed via dry deposition and $\sim 21 \%$ via wet deposition. In contrast, L-s is characterised by lower $\mathrm{SO}_{2}$ dry and wet deposition fluxes of $\sim 20 \%$ and $\sim 17 \%$, respectively. During L-s, $\sim 94 \%$ of the $\mathrm{SO}_{4}$ aerosol is wet deposited (mainly via nucleation scavenging of accumulation mode-sized $\left(0.1<d_{p}<1.0 \mu \mathrm{m}\right)$ particles), and $\sim 6 \%$ is dry deposited. This compares to $\sim 89 \%$ of the $\mathrm{SO}_{4}$ aerosol being wet deposited and $\sim 11 \%$ being dry deposited during L-w.

\subsection{Depletion of oxidants}

Our simulations reveal a significant impact of a Laki-style eruption on the principal oxidants $\left(\mathrm{OH}\right.$ and $\left.\mathrm{H}_{2} \mathrm{O}_{2}\right)$ involved in the chemical conversion of $\mathrm{SO}_{2}$ to $\mathrm{SO}_{4}$ aerosol. Figure 5 shows zonal 3-month mean change in $\mathrm{H}_{2} \mathrm{O}_{2}$ and $\mathrm{OH}$ concentrations while Fig. $6 \mathrm{a}$ and $\mathrm{b}$ show the spatial distribution of $\mathrm{H}_{2} \mathrm{O}_{2}$ and $\mathrm{OH}$ at altitudes where perturbations are largest. In the lowermost troposphere, $\mathrm{H}_{2} \mathrm{O}_{2}$ is the main oxidant of $\mathrm{SO}_{2}$ in low-level cloud water, so it is depleted by the excess volcanic $\mathrm{SO}_{2}$ emitted from the lava flows and re-entrained $\mathrm{SO}_{2}$ from higher altitudes. In contrast, $\mathrm{OH}$ is the principal oxidant above $\sim 3 \mathrm{~km}$, so it is depleted by the excess volcanic $\mathrm{SO}_{2}$ emitted from the vent system.

L-s and L-w have a similar impact on zonal 3-month mean $\mathrm{OH}$ concentrations compared to the unperturbed simulations, depleting them by up to $\sim 55 \%$ at $\sim 10 \mathrm{~km}$ altitude at high northern latitudes, where $\mathrm{SO}_{2}$ concentrations are highest. However, L-w exhibits a greater impact on $\mathrm{OH}$ at $\sim 10 \mathrm{~km}$ in the latitude band from $70^{\circ} \mathrm{N}$ to $90^{\circ} \mathrm{N}$, which is a result of naturally lower $\mathrm{OH}$ production rates during wintertime.

Zonal 3-month mean $\mathrm{H}_{2} \mathrm{O}_{2}$ concentrations for L-s are depleted by up to $35 \%$ in the lowermost troposphere but enhanced by over $150 \%$ in the Arctic free troposphere. The free troposphere enhancements in $\mathrm{H}_{2} \mathrm{O}_{2}$ are due to the gas phase reaction of $\mathrm{SO}_{2}$ with $\mathrm{OH}$ :

$\mathrm{OH}+\mathrm{SO}_{2}\left(+\mathrm{O}_{2}+\mathrm{H}_{2} \mathrm{O}\right) \rightarrow \mathrm{H}_{2} \mathrm{SO}_{4}+\mathrm{HO}_{2}$

which is the only source of atmospheric $\mathrm{H}_{2} \mathrm{O}_{2}$. 


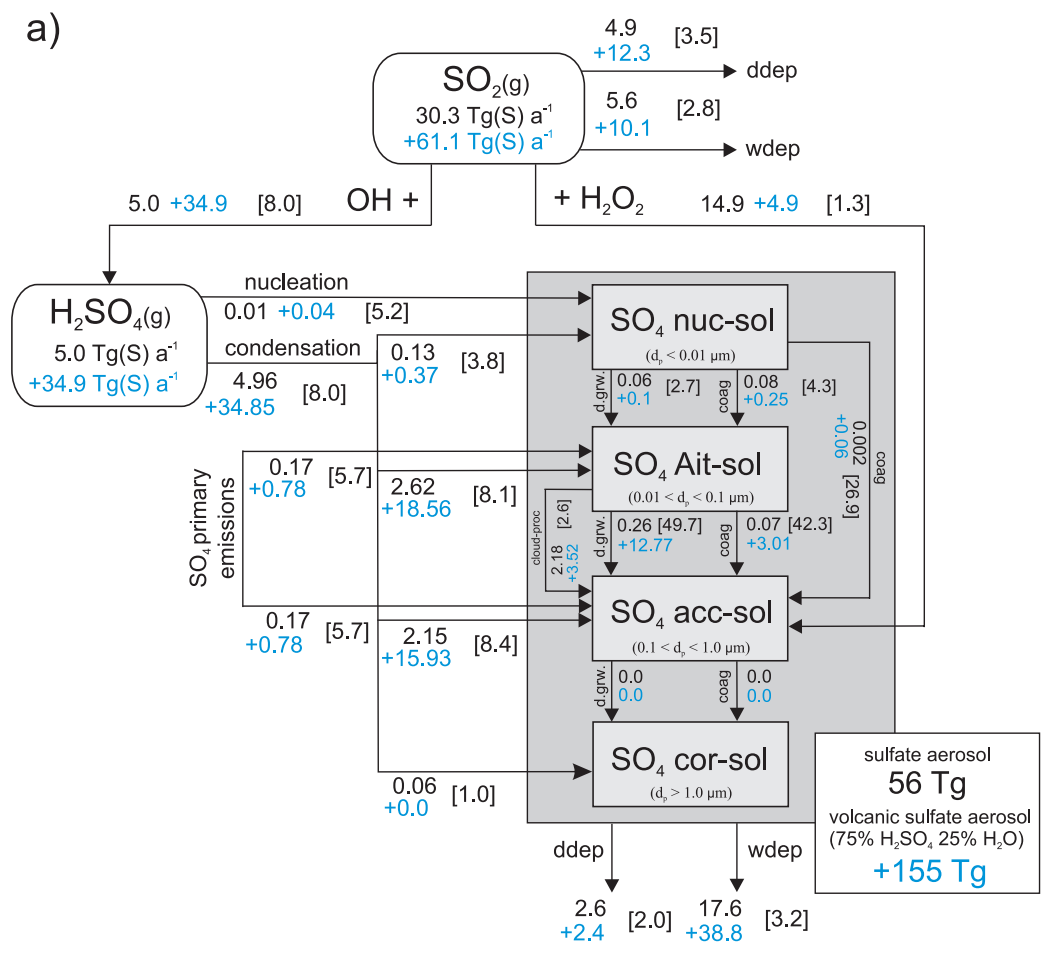

Fig. 4a. Simulated global 12-month mean sulphur budget showing fluxes in $\operatorname{Tg}(\mathrm{S}) \mathrm{a}^{-1}$ with blue colours showing absolute changes for L-s, black colours showing the unperturbed run, and ratio of L-s to unperturbed in parentheses. Abbreviations: ddep = dry deposition; wdep=wet deposition; d.grw $=$ direct growth; coag $=$ coagulation; cloud-proc=cloud processing of Aitken mode-sized particles.

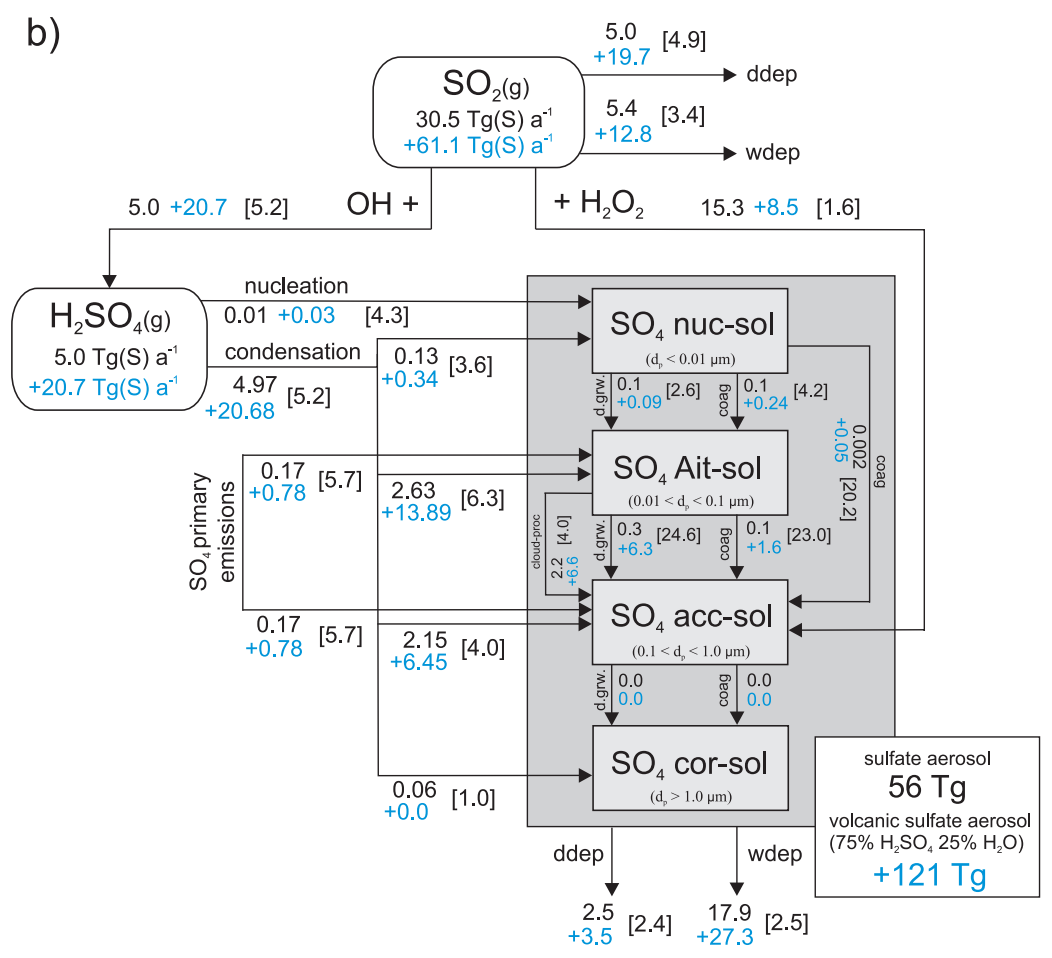

Fig. 4b. As Fig. 4a but 12-month mean sulphur budget shown for L-w. 
Table 1. Comparison with previous modelling studies and literature-based estimates.

\begin{tabular}{|c|c|c|c|c|}
\hline Diagnostic & This study & S2003 & O2006 & Obs. and lit. \\
\hline Peak $\mathrm{SO}_{2}$ burden $(\mathrm{Tg})$ & $29 ; 23^{*}$ & $9-17^{*}$ & 37 & - \\
\hline Peak $\mathrm{SO}_{4}$ burden $(\mathrm{Tg})$ & 14 & $4.2-5.1$ & 60 & - \\
\hline JJA mean $\mathrm{SO}_{2}$ residence time (days) & 23 & $9-18$ & $18^{\mathrm{a}}$ & - \\
\hline $\mathrm{JJA}_{\text {mean } \mathrm{SO}_{4} \text { residence time (days) }}$ & 9 & $7-8$ & $27^{\mathrm{a}}$ & - \\
\hline Greenl. $\mathrm{SO}_{4}$ dep. $\left(\mathrm{kg} \mathrm{SO}_{4} \mathrm{~km}^{-2}\right)$ & $190-650 ; 1500$ & $105-195$ & $165-300$ & $62-324^{\mathrm{b}, \mathrm{c}}$ \\
\hline Peak NH mean AOD & 0.3 & - & 0.5 & $0.4-0.9^{\mathrm{d}}$ \\
\hline Volcanic $\mathrm{SO}_{4}$ aerosol yield $(\mathrm{Tg})$ & 155 & $71-92$ & $163-166$ & $46-374^{\mathrm{e}} ; 175^{* *}$ \\
\hline
\end{tabular}

* = June-July-August mean; ${ }^{* *}=$ average; S2003 = Stevenson et al. (2003); O2006= Oman et al. (2006a)

$\mathrm{a}=\mathrm{L}$. Oman (personal communication, 2010)

$\mathrm{b}=$ Clausen and Hammer (1988)

$\mathrm{c}=$ Mosley-Thompson et al. (2003)

$\mathrm{d}=$ Thordarson and Self (2003)

$\mathrm{e}=$ Oman et al. (2006a, Table 1)

In L-w, zonal 3-month mean boundary layer $\mathrm{H}_{2} \mathrm{O}_{2}$ concentrations show a complete depletion at high northern latitudes $\left(>80^{\circ} \mathrm{N}\right)$, and are depleted by $>80 \%$ between $45^{\circ} \mathrm{N}$ and $75^{\circ} \mathrm{N}$. In contrast, $\mathrm{H}_{2} \mathrm{O}_{2}$ concentrations at $\sim 1 \mathrm{~km}$ altitude for L-s exhibit on average a ratio of 0.75 for the latitude band $60^{\circ} \mathrm{N}$ to $90^{\circ} \mathrm{N}$, and depletion is generally latitudinally and vertically more confined when compared to L-w (see also Fig. 6a). The wider extent of $\mathrm{H}_{2} \mathrm{O}_{2}$ depletion in winter can be explained by the longer $\mathrm{SO}_{2}$ residence time, which allows long-range transport of the $\mathrm{SO}_{2}$ and depletion of $\mathrm{H}_{2} \mathrm{O}_{2}$ further away from the $\mathrm{SO}_{2}$ source.

\subsection{Comparison with other modelling studies and observations}

\subsubsection{Other modelling studies}

Table 1 compares key diagnostics (from the L-s simulation) such as burden, residence times and yield (the integrated mass of volcanic aerosol produced in the year after the onset of the eruption) with previous modelling studies (Stevenson et al., 2003; Oman et al., 2006a) and literature-based estimates and observations (Clausen and Hammer, 1988; Mosley-Thompson et al., 2003; Thordarson and Self, 2003). GLOMAP-mode predicts a similar peak global $\mathrm{SO}_{2}$ burden when compared to previous modelling studies (Stevenson et al., 2003; Oman et al., 2006a). However, our peak $\mathrm{SO}_{4}$ burden is one quarter of that calculated by Oman et al. (2006a), and up to a factor 3.3 higher when compared to Stevenson et al. (2003). June-July-August (JJA) mean $\mathrm{SO}_{2}$ residence times compare well between all three studies. However, JJA mean $\mathrm{SO}_{4}$ residence times are at least a factor 3 longer in the Oman et al. (2006a) study when compared to both, our study and the Stevenson et al. (2003) study. We find a total volcanic aerosol yield of $155 \mathrm{Tg}$ for L-s (assuming a composition of
$75 \% \mathrm{H}_{2} \mathrm{SO}_{4}$ and $25 \% \mathrm{H}_{2} \mathrm{O}$ ), which is remarkably close to the 163-166 Tg calculated by Oman et al. (2006a) but higher than the 71-92 Tg found by Stevenson et al. (2003). In contrast to L-s, the total $\mathrm{SO}_{4}$ aerosol yield for L-w is, with $121 \mathrm{Tg}$ of volcanic aerosol, substantially lower, implying a less profound impact on radiation.

In summary, Table 1 shows that there is a fair amount of consistency between our study and previous modelling studies (Stevenson et al., 2003; Oman et al., 2006a) with the differences between the models being within the range of uncertainty seen in previous model intercomparision studies (e.g., Textor et al., 2006). For example, our model chemistry produces an amount of volcanic aerosol similar to that of the GISS modelE used by Oman et al. (2006a) but our JJA mean $\mathrm{SO}_{4}$ residence time and peak $\mathrm{SO}_{4}$ burden are lower when compared to Oman et al. (2006a). These differences indicate that either our model tends to remove sulphate too fast or that the assumption about the effective radius of the Laki aerosol used in the Oman et al. (2006a) study is inconsistent when compared to the aerosol size distribution simulated using GLOMAP-mode (see Sect. 3.4).

Overall, we consider GLOMAP-mode to be superior when calculating the impact of volcanic aerosol on climate. Compared to previous Laki modelling studies (Stevenson et al., 2003; Chenet et al., 2005; Oman et al., 2006a) we simulate particle number concentration and component mass concentrations using a sectional two-moment scheme, thus allowing the particle size distribution to evolve freely instead of prescribing a globally uniform aerosol size to initialise the model simulation (Oman et al., 2006a). GLOMAP-mode accounts for microphysical processes such as nucleation, condensation and coagulation that drive the evolution of the aerosol size distribution. Using sectional two-moment aerosol schemes such as GLOMAP-mode will thus allow 
a)

b)
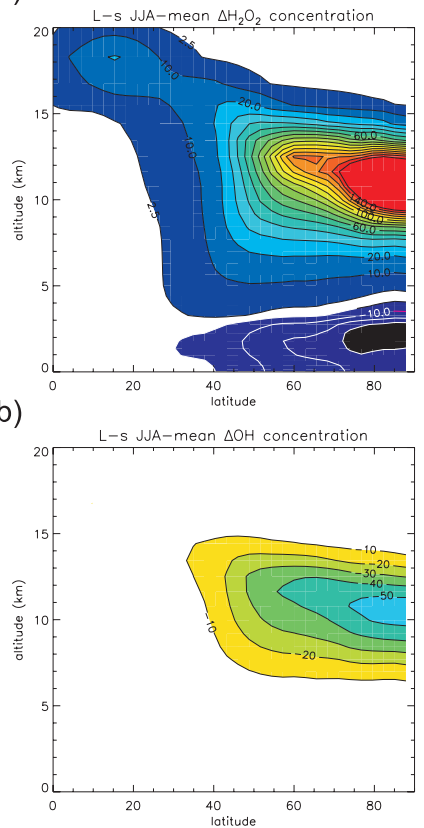

c)
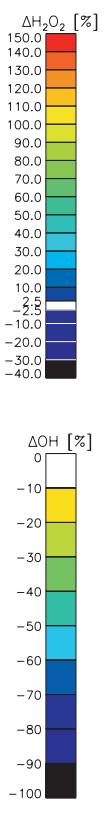

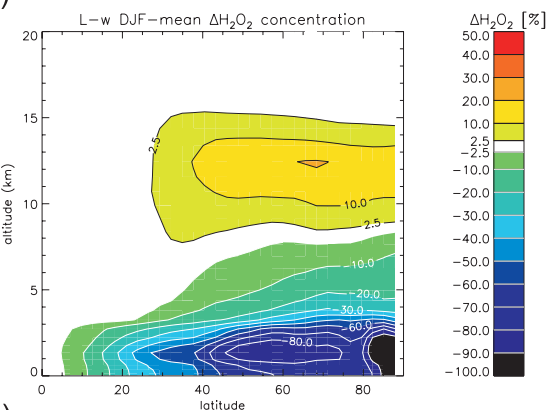

d)

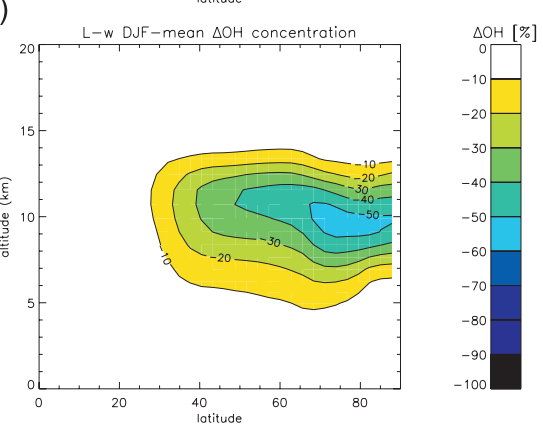

Fig. 5. Simulated relative changes in zonal 3-month mean $\mathrm{H}_{2} \mathrm{O}_{2}$ and $\mathrm{OH}$ concentrations averaged over the Northern Hemisphere for (a) L-s JJA-mean $\mathrm{H}_{2} \mathrm{O}_{2}$ concentration change, (b) L-s JJA-mean $\mathrm{OH}$ concentration change, (c) L-w DJF-mean $\mathrm{H}_{2} \mathrm{O}_{2}$ concentration change, and (d) L-w DJF-mean OH concentration change. JJA=June-July-August; DJF=December-January-February.

a)

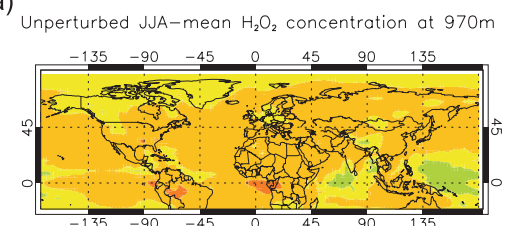

b)

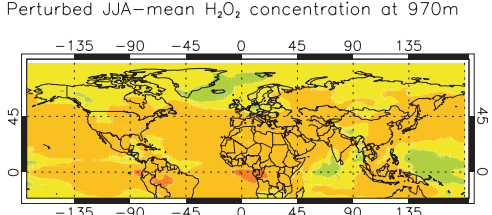

c)

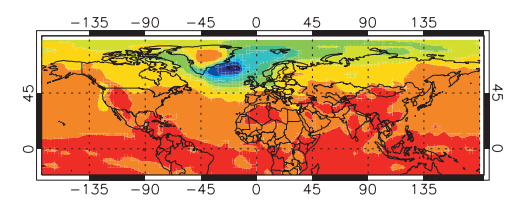

d) Unperturbed DJF-mean $\mathrm{H}_{2} \mathrm{O}_{2}$ concentration ot $970 \mathrm{~m}$

e)

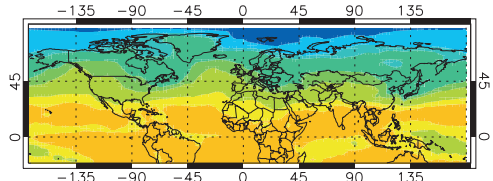

Perturbed DJF-mean $\mathrm{H}_{2} \mathrm{O}_{2}$ concentration at $970 \mathrm{~m}$

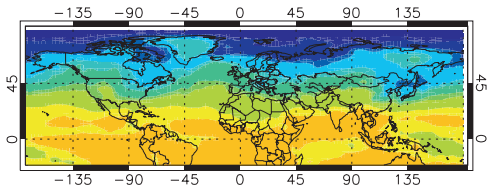

f)

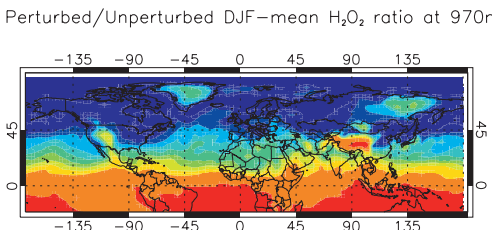

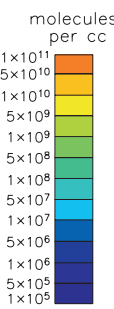

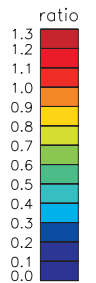

Fig. 6a. Simulated 3-month mean $\mathrm{H}_{2} \mathrm{O}_{2}$ concentration at low-level cloud altitude $(970 \mathrm{~m}$ ) for (a) L-s unperturbed run, (b) L-s perturbed run, (c) L-s ratio perturbed to unperturbed run, (d) L-w unperturbed run, (e) L-w perturbed run, (f) L-w ratio perturbed to unperturbed run. JJA=June-July-August; DJF=December-January-February.

simulating the aerosol indirect effects following volcanic eruptions more realistically than using e.g. mass-only schemes.

\subsubsection{Sulphate deposition record in ice-cores}

Several authors have measured acidity and total $\mathrm{SO}_{4}$ in Greenland and Svalbard ice cores in order to reconstruct 
a)

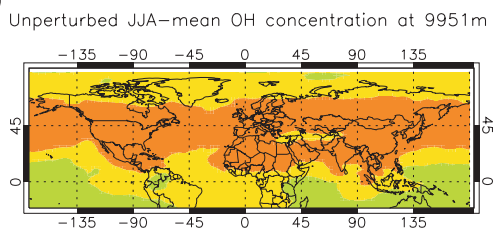

b)

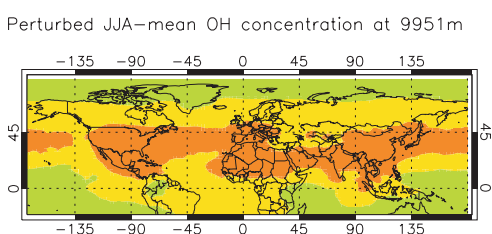

c)

Perturbed/Unperturbed JJA-mean $\mathrm{OH}$ ratio at $9951 \mathrm{~m}$

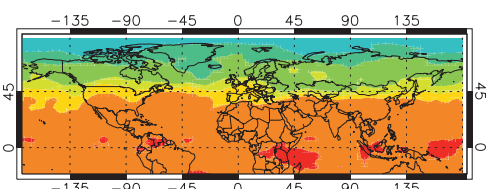

d)

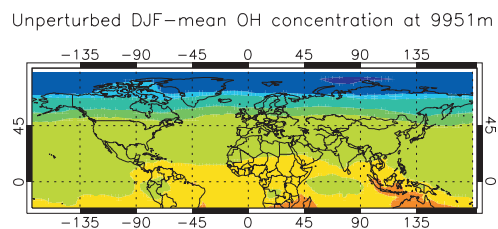

e)

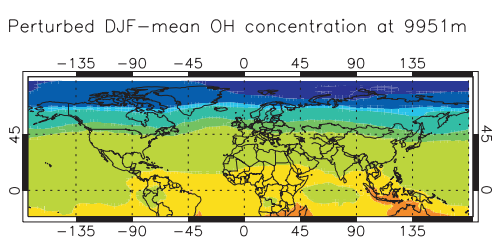

f)

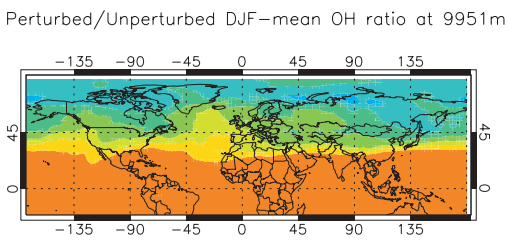

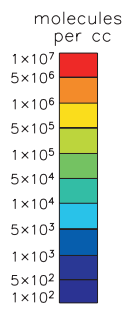

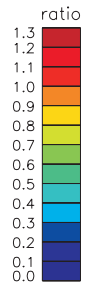

Fig. 6b. Simulated 3-month OH concentration at $9951 \mathrm{~m}$ altitude for (a) L-s unperturbed run, (b) L-s perturbed run, (c) L-s ratio perturbed to unperturbed run, (d) L-w unperturbed run, (e) L-w perturbed run, (f) L-w ratio perturbed to unperturbed run. JJA=June-July-August; DJF=December-January-February.

the total volcanic $\mathrm{SO}_{4}$ deposition $\left(\mathrm{kg} \mathrm{km}^{-2}\right)$ and the volcanic aerosol loading of the 1783-1784 AD Laki eruption (e.g., Clausen and Hammer, 1988; Fiacco et al., 1994; Zielinski et al., 1997; Mosley-Thompson et al., 2003). We compare our modelled total $\mathrm{SO}_{4}$ deposition over 12 months following the onset of L-s (Fig. 7a) with measurements from Greenland (Clausen and Hammer, 1988; Mosley-Thompson et al., 2003) and Svalbard (Kekonen et al., 2005). Generally, Greenland ice core measurements reveal a highly spatially variable amount of total $\mathrm{SO}_{4}$ deposition, ranging from $62 \mathrm{~kg} \mathrm{~km}^{-2}$ to $294 \mathrm{~kg} \mathrm{~km}^{-2}$ in 11 ice cores (Clausen and Hammer, 1988) and from 80 to $324 \mathrm{~kg} \mathrm{~km}^{-2}$ in 6 ice cores (Mosley-Thompson et al., 2003). GLOMAP-mode predicts a total $\mathrm{SO}_{4}$ deposition ranging from $\sim 190 \mathrm{~kg} \mathrm{~km}^{-2}$ over northernmost Greenland to $\sim 650 \mathrm{~kg} \mathrm{~km}^{-2}$ over Central Greenland with the majority being deposited during the first 3 months after the onset of the eruption. Up to $\sim 1500 \mathrm{~kg} \mathrm{~km}^{-2}$ are deposited over Northwest Greenland and the south-westernmost tip. GLOMAP mode predicts the total $\mathrm{SO}_{4}$ deposition over Greenland with a mean bias of 4.2 when comparing our results to measurements in 12 ice cores (Mosley-Thompson et al., 2003; Clausen and Hammer, 1988, Table V). Generally, the lowest model biases (1.3 and 1.6) are calculated for Central Greenland cores D3 and Milcent, and the highest biases (6.0 and 5.8) are calculated for the Raven core in the South West and the Humboldt core in Northern Greenland (Fig. 7b). For the Lomonosovfonna icecore in Svalbard, the model predicts a total $\mathrm{SO}_{4}$ deposition of $570 \mathrm{~kg} \mathrm{~km}^{-2}$ with the majority being deposited during the first 6 months after the onset of the eruption. This compares to $390 \mathrm{~kg} \mathrm{~km}^{-2}$ being preserved in the Lomonosovfonna icecore (Kekonen et al., 2005).

Korhonen et al. (2008) showed that GLOMAP may remove particles too efficiently over Arctic regions, which is most likely due to the simplified treatment of nucleation scavenging in frontal rain clouds. We note that, despite the model overpredicting the amount of $\mathrm{SO}_{4}$ deposited to Greenland, we have confidence in our results as Table 1 shows that other diagnostics are in good agreement with previous modelling studies by Stevenson et al. (2003) and Oman et al. (2006a). Moreover, our other study (Mann et al., 2010) has shown that the GLOMAP-mode performs well when compared to present-day observations. For example, presentday global annual mean surface $\mathrm{SO}_{4}$ concentrations predicted by GLOMAP-mode are in very good agreement with a range of observational datasets (Mann et al., 2010, and references therein). Furthermore, details on the performance of GLOMAP-mode can be found on the AEROCOM model intercomparison website (http://dataipsl.ipsl.jussieu.fr/cgi-bin/ AEROCOM/aerocom/surfobs_annualrs.pl). We also note that the deposition of $\mathrm{SO}_{4}$ to a particular location is strongly influenced by the meteorology used to force the model. For example, when forcing the model using ECMWF reanalyses for the year 2000, instead of 2003, the deposition pattern is similar but the magnitude of the total $\mathrm{SO}_{4}$ deposition between 2003 and 2000 ranges locally from $72 \%$ less to $140 \%$ more total deposition over Greenland and adjacent regions. We believe that only using the $1783 \mathrm{AD}$ meteorology would be a conclusive test for any model. 
a)

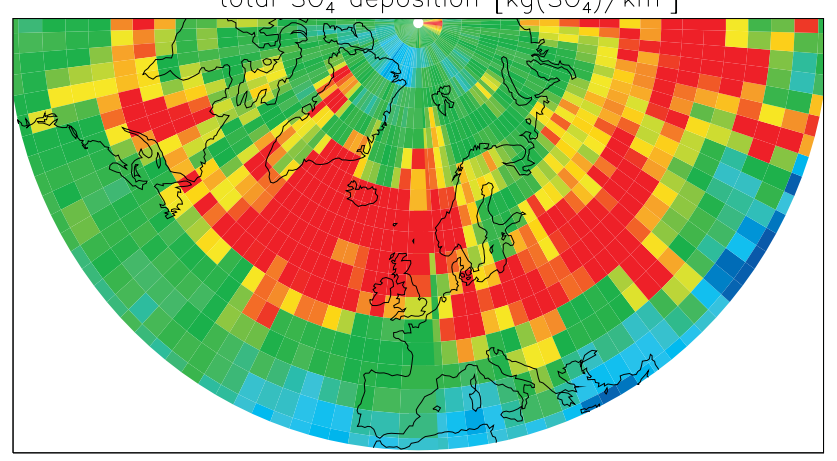

$\mathrm{SO}_{4}$ in $\mathrm{kg}\left(\mathrm{SO}_{4}\right) / \mathrm{km}^{2}$

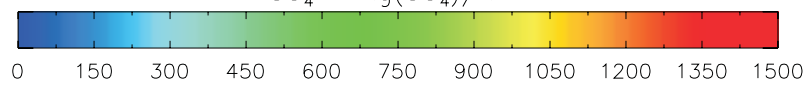

b)

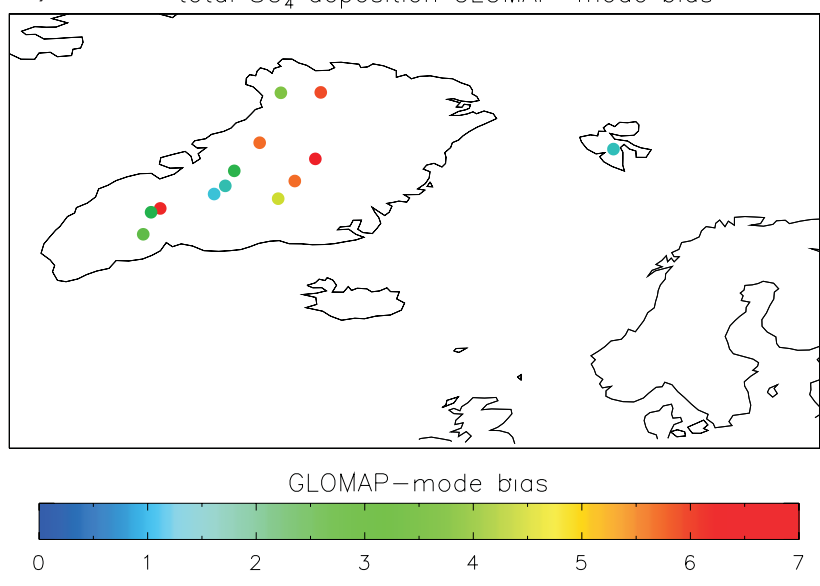

Fig. 7. (a) Total $\mathrm{SO}_{4}$ deposition $\left[\mathrm{kg}\left(\mathrm{SO}_{4}\right) / \mathrm{km}^{2}\right]$ following the first 12 months after the onset of the Laki eruption shown for the Northern Hemisphere. (b) Bias of modelled total $\mathrm{SO}_{4}$ deposition $\left[\mathrm{kg}\left(\mathrm{SO}_{4}\right) / \mathrm{km}^{2}\right]$ when compared to ice core measurements in Greenland (Mosley-Thompson et al., 2003; Clausen and Hammer, 1988, Table V) and Svalbard (Kekonen et al., 2005).

\subsection{Aerosol microphysical processes and size distribution}

Figure 8 shows simulated zonal 3-month mean number-size distributions in the NH for L-s and L-w, and the respective unperturbed simulations.

In both L-s and L-w there is a substantial effect on the sizes and number concentrations of particles throughout the atmosphere. Moreover, the aerosol processes controlling the evolution of the size distribution are noticeably different for the summer and winter scenarios when compared to the unperturbed atmosphere (see Fig. 4a, b).

In both L-s and L-w the upper parts of the atmosphere are characterised by an increase in nucleation mode $\left(d_{p}<0.01 \mu \mathrm{m}\right)$ and Aitken mode $\left(0.01<d_{p}<0.1 \mu \mathrm{m}\right)$ particle concentrations due to more favourable conditions for nucleation at high altitudes (Spracklen et al., 2005a). In L-s, zonal 3 -month mean nucleation mode particle concentrations at $15 \mathrm{~km}$ are a factor $\sim 4$ higher than in the unperturbed atmosphere, and they are a factor $\sim 2$ higher in L-w.

Accumulation mode particles are the most relevant to climate, and below about $8 \mathrm{~km}$ the summer eruption increases their number concentration by a factor $\sim 9$. The cause of the very substantial effects on Aitken and accumulation mode particle concentrations throughout the atmosphere is the combination of increased nucleation in the high free troposphere/upper troposphere and the availability of $\mathrm{H}_{2} \mathrm{SO}_{4}$ vapour for condensational growth to larger sizes. Nucleation mode particles in the free troposphere grow by $\mathrm{H}_{2} \mathrm{SO}_{4}$ condensation and coagulation as they descend. This in turn, leads to abundant Aitken mode particles with changes in concentration of up to $1695 \mathrm{~cm}^{-3}$ at altitudes from 7 to $12 \mathrm{~km}$ for L-s.

Figure 4a highlights how much the microphysical processes change in response to the summertime eruption when compared to the unperturbed atmosphere. Condensation of $\mathrm{H}_{2} \mathrm{SO}_{4}$ on to Aitken particles rises by a factor $\sim 8$ in the 12 months after the onset of L-s. The significant increase in Aitken particles also means that their coagulation adds a factor $\sim 42$ more mass to the accumulation mode than in the unperturbed atmosphere. Moreover, the abundant $\mathrm{H}_{2} \mathrm{SO}_{4}$ vapour means that the direct growth of Aitken mode particles into the accumulation mode increases by a factor $\sim 50$, accounting for around one-fifth of the accumulation mode $\mathrm{SO}_{4}$ mass. Likewise, direct $\mathrm{H}_{2} \mathrm{SO}_{4}$ vapour condensation on to accumulation mode particles increases by a factor $\sim 8$ and accounts for around one-third of the accumulation mode $\mathrm{SO}_{4}$ mass.

The only process not greatly enhanced during the first 12 months after the onset of $\mathrm{L}$-s is in-cloud $\mathrm{SO}_{4}$ production (i.e. aqueous-phase oxidation of $\mathrm{SO}_{2}$ by $\mathrm{H}_{2} \mathrm{O}_{2}$ to form $\mathrm{SO}_{4}$ on Aitken and accumulation mode particles), which is enhanced by merely a factor 1.5 compared to the unperturbed run. This small increase in in-cloud $\mathrm{SO}_{4}$ production is due to the suppression of the main aqueous phase oxidant, $\mathrm{H}_{2} \mathrm{O}_{2}$ (Fig. 5). Thus, in-cloud $\mathrm{SO}_{4}$ production contributes only a small fraction of the accumulation mode mass in the perturbed atmosphere. In stark contrast, in-cloud $\mathrm{SO}_{4}$ production is the main pathway for the increase of the accumulation mode in the unperturbed atmosphere and adds about a factor 8 more $\mathrm{SO}_{4}$ than the second most important process, condensation of $\mathrm{H}_{2} \mathrm{SO}_{4}$ vapour.

To summarise the budget for L-s: in the 12 months after the onset of the eruption, $\mathrm{H}_{2} \mathrm{SO}_{4}$ condensation on the accumulation mode and growth of Aitken mode particles into the accumulation mode increase to such an extent (from 2.5 to $34 \mathrm{Tg}(\mathrm{S}) \mathrm{a}^{-1}$ ) that, alongside the small increase of in-cloud $\mathrm{SO}_{4}$ production (from 17 to $25 \mathrm{Tg}(\mathrm{S}) \mathrm{a}^{-1}$ ), these processes become approximately equally important in determining the mass of the accumulation mode. 
a)

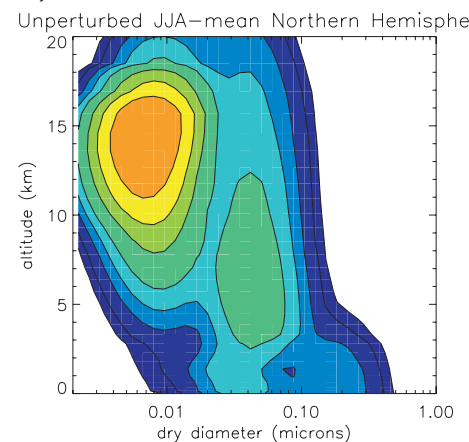

c)

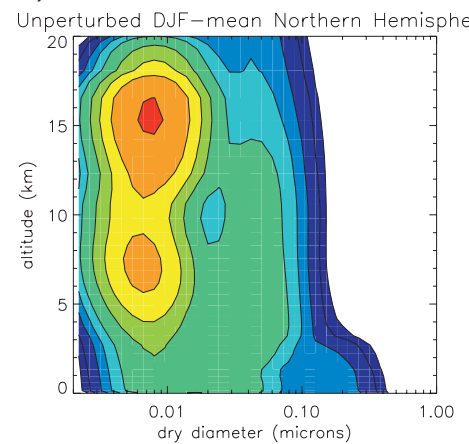

b)

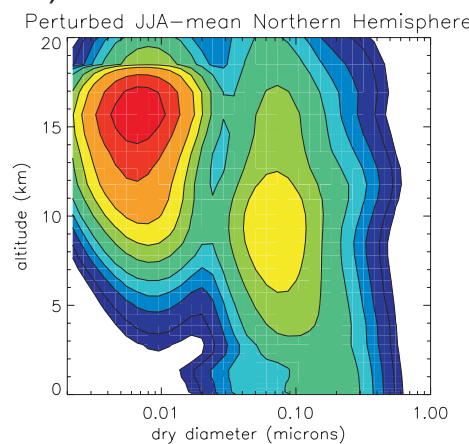

d)

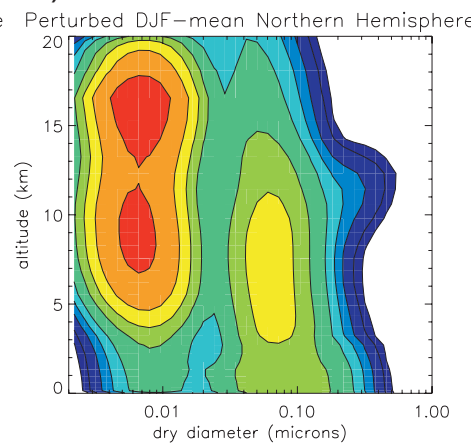

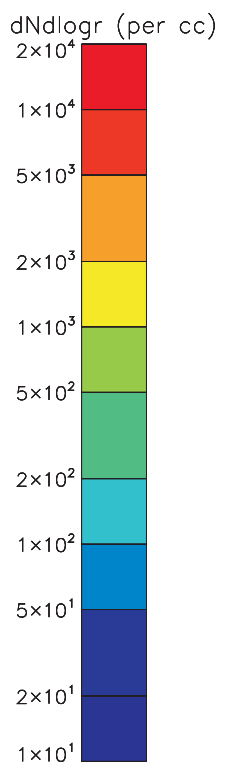

Fig. 8. Simulated zonal 3-month mean number-size distribution averaged over the Northern Hemisphere for (a) L-s unperturbed run, (b) L-s perturbed run, (c) L-w unperturbed run, (d) L-w perturbed run. With nucleation mode: $\left(d_{p}<0.01 \mu \mathrm{m}\right)$; Aitken mode: $\left(0.01<d_{p}<0.1 \mu \mathrm{m}\right)$; accumulation mode: $\left(0.1<d_{p}<1.0 \mu \mathrm{m}\right)$. JJA=June-July-August; DJF=December-January-February.

a)

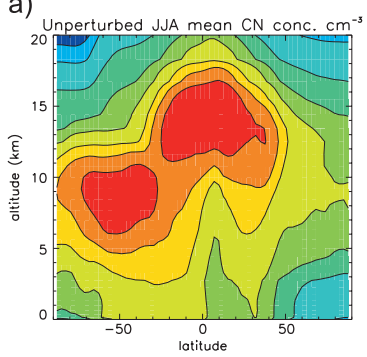

d)

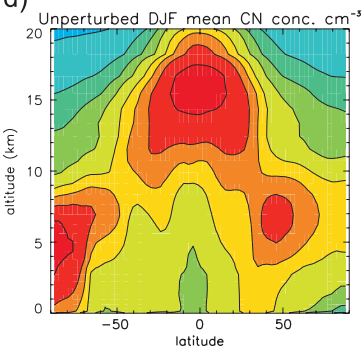

b)

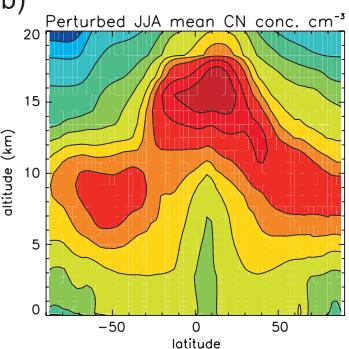

e)

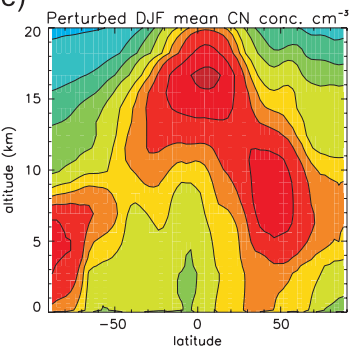

c)

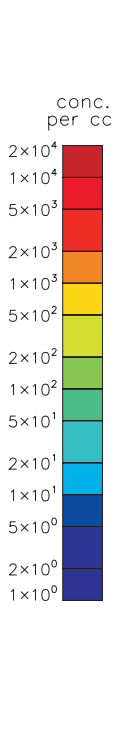

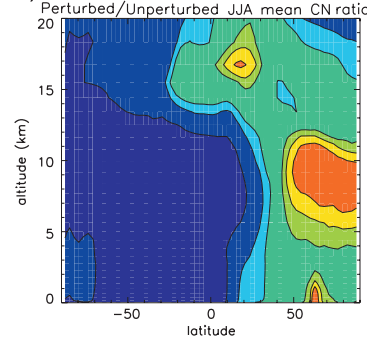

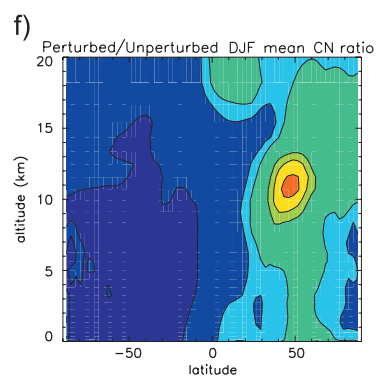

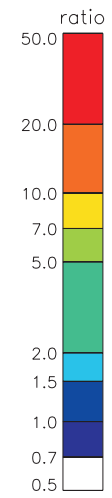

Fig. 9. Simulated zonal 3-month mean $\mathrm{CN}$ concentrations per cubic centimeter (per cc) for L-s: (a) unperturbed run, (b) perturbed run, (c) ratio of perturbed to unperturbed; and for L-w: (d) unperturbed run, (e) perturbed run, (f) ratio of perturbed to unperturbed. JJA=JuneJuly-August; DJF=December-January-February. 


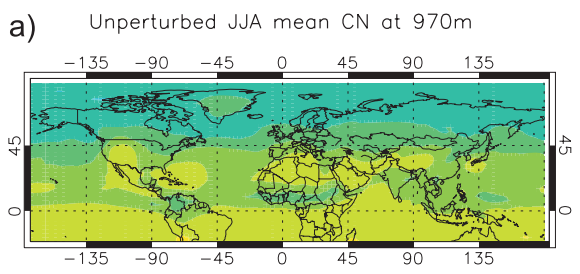

b) Perturbed JJA mean $\mathrm{CN}$ at $970 \mathrm{~m}$

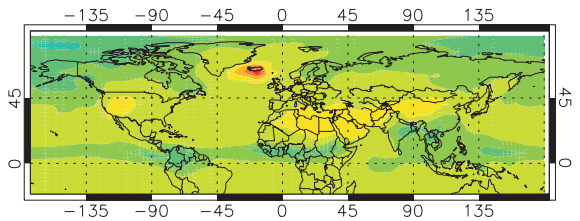

c)

Perturbed/Unperturbed JJA mean $\mathrm{CN}$ ratio at $970 \mathrm{~m}$

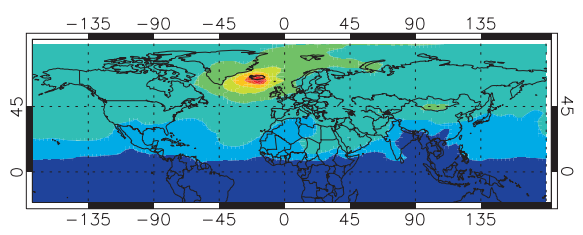

d) Unperturbed DJF mean $\mathrm{CN}$ at $970 \mathrm{~m}$

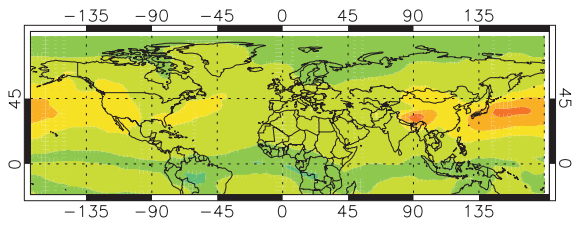

e) Perturbed DJF mean $\mathrm{CN}$ at $970 \mathrm{~m}$

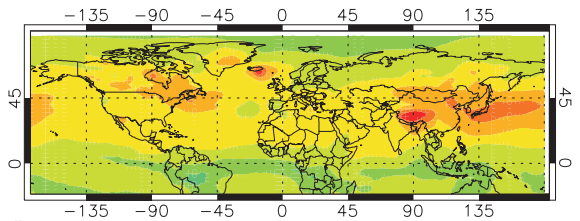

f)

Perturbed/Unperturbed DJF mean $\mathrm{CN}$ ratio at $970 \mathrm{~m}$

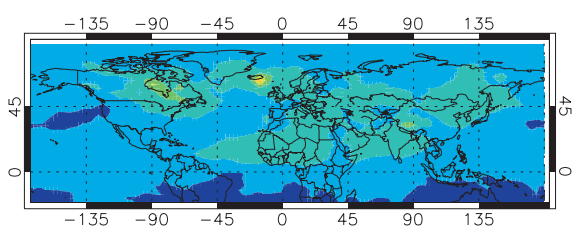

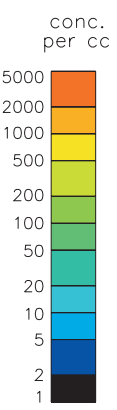

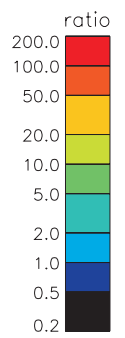

Fig. 10. Simulated 3-month mean CN concentrations per cubic centimeter (per cc) at $970 \mathrm{~m}$ altitude for L-s: (a) unperturbed run, (b) perturbed run, (c) ratio of perturbed to unperturbed; and for L-w: (d) unperturbed run, (e) perturbed run, (f) ratio of perturbed to unperturbed. JJA=June-July-August; DJF=December-January-February.

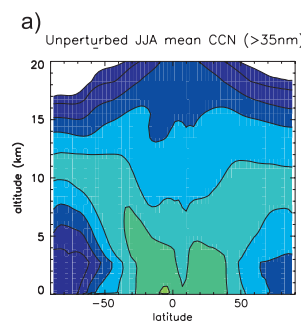

d)

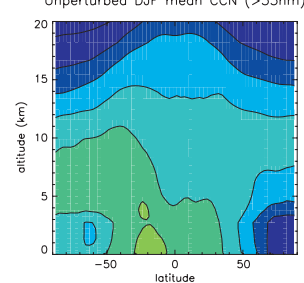

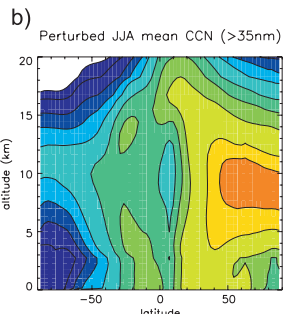

e)

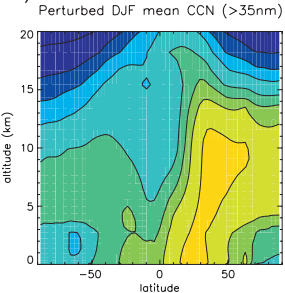

c)

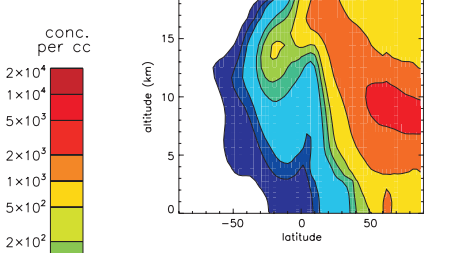

f)

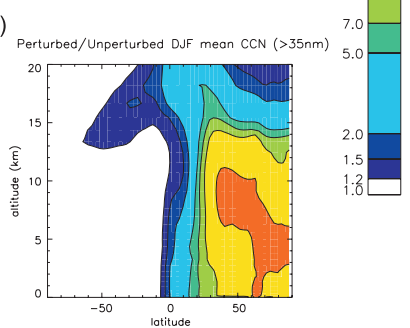

Fig. 11. Simulated zonal 3-month mean CCN concentrations (radius $>35 \mathrm{~nm}$, supersaturation=0.22\%) per cubic centimeter (per cc) for L-s: (a) unperturbed run, (b) perturbed run, (c) ratio of perturbed to unperturbed; and for L-w: (d) unperturbed run, (e) perturbed run, (f) ratio of perturbed to unperturbed. JJA=June-July-August; DJF=December-January-February.

In contrast, in the 12 months after the onset of L-w, incloud $\mathrm{SO}_{4}$ production is still the dominant process determining the mass of accumulation mode $\mathrm{SO}_{4}$ due to less substantial increases in $\mathrm{H}_{2} \mathrm{SO}_{4}$ vapour condensation and direct growth of Aitken mode particles (from 2.5 to $16.0 \mathrm{Tg}(\mathrm{S}) \mathrm{a}^{-1}$ ) alongside a large increase in in-cloud $\mathrm{SO}_{4}$ production (from 18 to $33 \mathrm{Tg}(\mathrm{S}) \mathrm{a}^{-1}$ ) (Fig. 4bb). The dominance of in-cloud oxidation is a result of the less efficient conversion of $\mathrm{SO}_{2}$ to $\mathrm{SO}_{4}$ via $\mathrm{OH}$ during the winter months.

These results indicate that aerosol microphysical processes are fundamentally altered after the Laki eruption with the timing of the onset of the eruption playing an important role in determining the microphysical processes dominating the evolution of the aerosol size distribution. 
a) Unperturbed JJA mean $\mathrm{CCN}$ at $970 \mathrm{~m}$

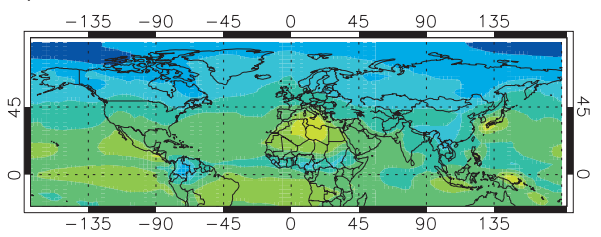

b) Perturbed JJA mean $\mathrm{CCN}$ at $970 \mathrm{~m}$

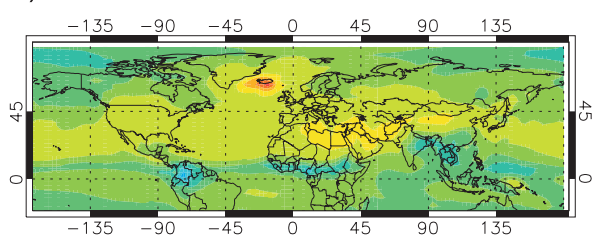

c) Change in JJA mean CCN at $970 \mathrm{~m}$

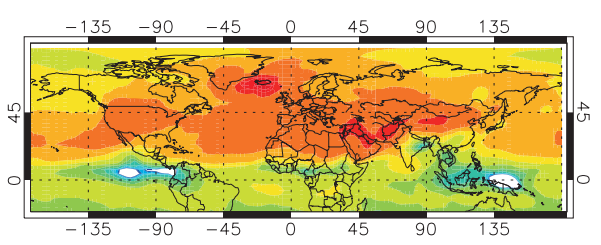

d) Unperturbed DJF mean $\mathrm{CCN}$ at $970 \mathrm{~m}$

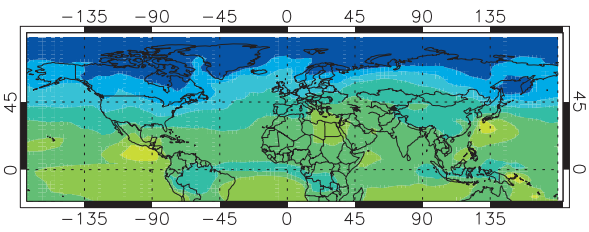

e) Perturbed DJF mean $\mathrm{CCN}$ at $970 \mathrm{~m}$

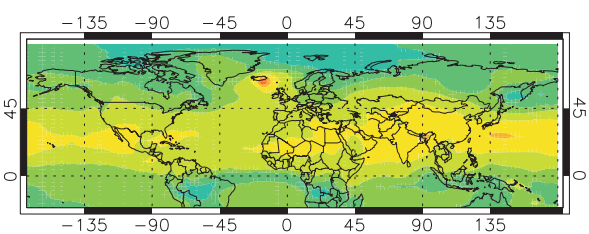

f) Change in DJF mean CCN at $970 \mathrm{~m}$

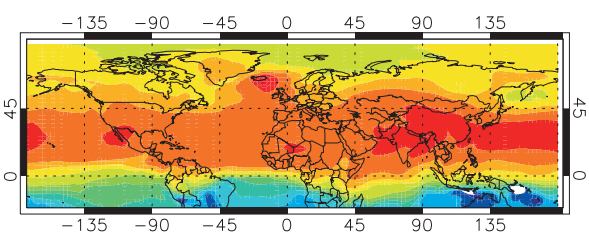

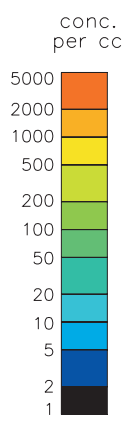

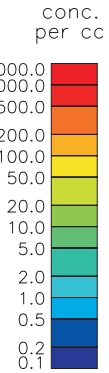

Fig. 12. Simulated 3 -month mean $\mathrm{CCN}$ concentrations (radius $>35 \mathrm{~nm}$, supersaturation=0.22\%) per cubic centimeter (per cc) for L-s: (a) unperturbed run, (b) perturbed run, (c) absolute change; and for L-w: (d) unperturbed run, (e) perturbed run, (f) absolute change. JJA=June-July-August; DJF=December-January-February.

\subsection{Impact on particle concentrations and $\mathrm{CCN}$ concentrations}

\subsubsection{Total particle concentrations}

Figure 9 shows zonal mean total particle concentrations averaged over the first 3 months for L-s and L-w, together with the unperturbed runs and the ratio of the volcanically perturbed to the respective unperturbed period. Here we define the total particle concentration in terms of the frequently used term condensation nuclei $(\mathrm{CN})$, counted as all particles larger than $3 \mathrm{~nm}$ in diameter.

For L-s, the model predicts an increase in $\mathrm{CN}$ concentrations of up to a factor 16 at high northern latitudes at 8 to $10 \mathrm{~km}$ altitude (corresponding to increases of up to $\sim 4400 \mathrm{~cm}^{-3}$ in this region). $\mathrm{CN}$ concentrations increase by as much as $16000 \mathrm{~cm}^{-3}$ at 15 to $18 \mathrm{~km}$ altitude at $\sim 10^{\circ} \mathrm{N}$, however, given the high natural background concentrations, the increase in this region (factor of $\sim 11$ ) is less than at higher northern latitudes. These results indicate that a fraction of the $\mathrm{SO}_{2}$ emitted from the vents into the lower stratosphere enhances nucleation, and that new particles are transported over long distances. This result is consistent with findings from previous studies (Spracklen et al., 2005a,b) suggesting that the $\mathrm{CN}$-formation potential is strongly enhanced in the cold upper troposphere where nucleation is most efficient. For $\mathrm{L}-\mathrm{w}$, the $\mathrm{CN}$ enhancement is a factor $\sim 12$, which is lower than for L-s. For L-w, maximum changes in $\mathrm{CN}$ concentrations of $7800 \mathrm{~cm}^{-3}$ are simulated at $\sim 9 \mathrm{~km}$ at around $45^{\circ} \mathrm{N}$. In the boundary layer, changes in $\mathrm{CN}$ concentrations are on average a factor $\sim 5$ for both L-s and L-w, while L-s exhibits a local peak (factor $\sim 16$ ) at around $1 \mathrm{~km}$ above the eruption site.

Both L-s and L-w show reduced 3-month mean CN concentrations in the $\mathrm{SH}$ relative to the unperturbed atmosphere, with the strongest reduction (factor $\sim 0.8$ ) in the upper troposphere at $30^{\circ} \mathrm{S}$. These reductions indicate that the net effect of the small increases in SH aerosol loading (see Sect. 3.1) is to enhance coagulation of existing and entrained particles. In the $\mathrm{NH}$, closer to the emissions of $\mathrm{SO}_{2}$, the net effect is to enhance nucleation of new particles from the produced $\mathrm{H}_{2} \mathrm{SO}_{4}$ vapour. However, the age of the pollution is older in the $\mathrm{SH}$ so most of the precursor gases have already been converted to aerosol.

Figure 10 shows the spatial distribution of 3-month mean $\mathrm{CN}$ concentrations at low-level cloud altitude $(\sim 1 \mathrm{~km})$ together with the ratio of the perturbed to the unperturbed simulations. Changes in concentrations reach a maximum of $\sim 14000 \mathrm{~cm}^{-3}$ close to the eruption site for L-s and $\sim 12000 \mathrm{~cm}^{-3}$ for L-w. These enhanced CN concentrations close to the eruption site are a result of nucleation of sulphuric acid vapour from the dry oxidation of $\mathrm{SO}_{2}$ emitted from the lava flows. The change in $\mathrm{NH} 3$-month mean $\mathrm{CN}$ concentrations is greater in the winter $\left(\sim 328 \mathrm{~cm}^{-3}\right)$ than in 
the summer $\left(\sim 135 \mathrm{~cm}^{-3}\right)$. The main source of these additional low-level $\mathrm{CN}$ on a hemispheric scale is from nucleation in the free troposphere and upper troposphere, and in the winter, with lower temperatures and higher humidities, nucleation occurs at lower altitudes and has a greater impact lower down than in the summer. For L-s CN concentrations increase on average to $\sim 450 \mathrm{~cm}^{-3}$ over large parts of North America, Greenland, Europe, the Middle East and Asia (i.e. an enhancement in $\mathrm{CN}$ concentration by a factor $\sim 2$ to $\sim 5$ in those regions). This far-reaching impact on $\mathrm{CN}$ concentrations is due to the long-range transport of nucleated particles as previously reported by Manktelow et al. (2009).

However, both eruptions have a relatively minor effect on CN concentrations at low-level cloud altitude south of the equator with L-s having a more profound and latitudinally more widespread effect (down by a factor 0.7) when compared to L-w (factor 0.9) due to higher $\mathrm{SO}_{2}$ and $\mathrm{SO}_{4}$ aerosol mixing ratios in the $\mathrm{SH}$ atmosphere for L-s.

\subsubsection{CCN concentrations}

The substantial change in the total $\mathrm{CN}$ population implies that both eruption scenarios have the potential to significantly contribute to the global $\mathrm{CCN}$ budget in the pre-industrial atmosphere, thus strongly impacting cloud microphysics. Here, $\mathrm{CCN}$ are counted as particles with a dry radius larger than $35 \mathrm{~nm}$, which is equivalent to the particles that would activate into cloud droplets at $0.22 \%$ supersaturation, which typically occurs in low-level stratocumulus clouds. Several microphysical processes lead to an increase in $\mathrm{CCN}$ concentrations: a) nucleation of $\mathrm{H}_{2} \mathrm{SO}_{4}$ vapour to $\mathrm{SO}_{4}$ aerosol and its subsequent growth to $\mathrm{CCN}$ sizes by coagulation and condensation; b) growth to $\mathrm{CCN}$ sizes by condensation of $\mathrm{H}_{2} \mathrm{SO}_{4}$ onto existing particles; and c) cloud processing of Aitken mode-sized particles. The balance of these pathways changes significantly in the volcanically perturbed simulations, as discussed in Sect. 3.4.

Figure 11 shows zonal mean concentrations of $\mathrm{CCN}$-sized particles averaged over the first 3 months for L-s and L-w, together with the unperturbed run, and the change in $\mathrm{CCN}$ concentrations. The model predicts an increase in $\mathrm{CCN}$ concentrations for L-s by a factor $>65$ in the upper troposphere, giving a change in zonal mean concentrations at $10 \mathrm{~km}$ altitude of $\sim 1400 \mathrm{~cm}^{-3}$. For comparison, Rogers et al. (1981) measured CCN concentrations (at 1\% supersaturation) around the plume of the Mt. St. Helens eruption in May 1981, ranging from 100 to $1000 \mathrm{~cm}^{-3}$ at an altitude of $13.6 \mathrm{~km}$. Boundary layer zonal 3-month mean $\mathrm{CCN}$ concentrations increase up to a factor $\sim 26$ to $\sim 415 \mathrm{~cm}^{-3}$ during L-s. The impact of $\mathrm{L}$-W on CCN concentrations at $10 \mathrm{~km}$ altitude is a factor of $\sim 24$, so less profound than during L-s.

Figure 11 also shows the impact of the eruption on $\mathrm{CCN}$ in the SH. In the L-s scenario zonal 3-month mean CCN concentrations increase by up to a factor 20 in the upper troposphere at $\sim 10^{\circ} \mathrm{S}$ where freshly nucleated particles subside in the general circulation and subsequently grow (by coagulation and condensation) to $\mathrm{CCN}$ sizes. Moreover, the model simulates an increase in boundary layer $\mathrm{CCN}$ concentrations of up to $35 \mathrm{~cm}^{-3}$ (factor 1.4) as far as $20^{\circ} \mathrm{S}$ (see also Fig. 12). The increase in $\mathrm{CCN}$ concentrations, together with the decrease in $\mathrm{CN}$ concentrations in the $\mathrm{SH}$ (Sect. 3.5.1), indicates a substantial impact of the eruption on microphysical processes leading to fewer, but larger-sized particles relative to the unperturbed atmosphere.

The main source of summertime $\mathrm{CCN}$ in the natural unperturbed lower troposphere in the pre-industrial period is from wind-dependent sea spray, which is rather weak during summer, and the formation of $\mathrm{SO}_{4}$ aerosol from $\mathrm{H}_{2} \mathrm{SO}_{4}$ vapour derived from the oxidation of marine dimethylsulfide (Korhonen et al., 2008). At present, these processes typically account for $\mathrm{CCN}$ concentrations of up to $100 \mathrm{~cm}^{-3}$ found in the lower troposphere in remote marine regions (Andreae, 2009). In our model (Fig. 12) we predict NH CCN concentrations at $1 \mathrm{~km}$ altitude ranging from $\sim 5$ to $450 \mathrm{~cm}^{-3}$ with a mean of $55 \mathrm{~cm}^{-3}$ under unperturbed pre-industrial conditions. Thus, with changes in NH 3-month mean $\mathrm{CCN}$ concentrations at low-level cloud altitude of $\sim 168 \mathrm{~cm}^{-3}$ for L-s and of $\sim 305 \mathrm{~cm}^{-3}$ for L-w, both eruptions would have completely dominated as a source of $\mathrm{CCN}$ in the pre-industrial atmosphere. Changes in peak 3-month mean $\mathrm{CCN}$ concentrations of $\sim 8000 \mathrm{~cm}^{-3}$ for L-s and $\sim 5500 \mathrm{~cm}^{-3}$ for L-w are simulated close to the eruption site, representing an enhancement by factors 543 and 594, respectively. Moreover, both eruptions significantly increase $\mathrm{CCN}$ concentrations at the altitude of low-level clouds over North America (factor $\sim 10$ for L-s and factor $\sim 17$ for L-w), Europe (factor $\sim 6$ for L-s and factor $\sim 8$ for L-w), Asia (factor $\sim 14$ for L-s and factor $\sim 11$ for L-w) and Northern Africa (factor $\sim 2$ for L-s and factor $\sim 5$ for $\mathrm{L}-\mathrm{w}$ ), as well as over the Pacific (factor $\sim 3$ for $\mathrm{L}-\mathrm{s}$ and factor $\sim 10$ for $\mathrm{L}-\mathrm{w})$.

The spatial distribution of $\mathrm{CN}$ and $\mathrm{CCN}$ changes will differ somewhat when forcing the model with different ECMWF reanalyses data. We further analysed a Laki simulation forced with year 2000 ECMWF fields and found that, on climatological relevant time-scales, the results are very similar for both, $\mathrm{CN}$ and $\mathrm{CCN}$ concentrations. For example, JJA zonal mean $\mathrm{CCN}$ number concentrations increase by a factor 74 in the upper troposphere (corresponding to maximum $\mathrm{CCN}$ changes of $1470 \mathrm{~cm}^{-3}$ ) when using reanalyses for the year 2000. JJA Northern Hemisphere mean CCN concentrations at low-level cloud altitude reach $270 \mathrm{~cm}^{-3}$ during the year 2003 and $290 \mathrm{~cm}^{-3}$ during the year 2000 . Similar to the year 2003 we find significant increases in CCN number concentrations far away from the eruption site for the simulations forced with year 2000 ECMWF reanalyses (e.g. North America: factor $\sim 11$; Europe: factor $\sim 5$; Asia: factor factor $\sim 12$ ). 


\section{Conclusions}

We used a comprehensive global aerosol microphysics model (GLOMAP-mode) to study the impact of the 1783-1784 AD Laki eruption on aerosol microphysical processes, including the nucleation of new particles and their growth to CCN. We used the dataset provided by Thordarson and Self (2003) to specify the $\mathrm{SO}_{2}$ emissions and, recognising that such an eruption is likely to occur again, we investigated the sensitivity of aerosol microphysical processes to the timing of the eruption by additionally simulating a hypothetical Laki eruption commencing in December.

Our principal finding is that the Laki eruption had the potential to dramatically impact global $\mathrm{CN}$ and $\mathrm{CCN}$ concentrations, with an increase of the total particle concentration in the upper troposphere by a factor of $\sim 16$ over large parts of the Northern Hemisphere during the first 3 months after the onset of the eruption. There are already several indications that particles released by volcanoes may act as CCN (e.g., Graf et al., 1997; Mather et al., 2004; Mather, 2008) and thus potentially alter cloud microphysical properties. We show that the Laki eruption had the potential to profoundly alter cloud microphysical properties and completely dominated as a source of $\mathrm{CCN}$ in the pre-industrial atmosphere by increasing zonal mean concentrations up to a factor $\sim 65$ in the upper troposphere and a factor $\sim 26$ in the boundary layer at high northern latitudes during the first 3 months following the onset of the eruption.

The model predicts that a Laki-style eruption has a very widespread effect on $\mathrm{CCN}$ concentrations. $\mathrm{CCN}$ concentrations at the altitude of low-level clouds are predicted to increase by a factor $\sim 14$ in Asia. Such a long-range effect is consistent with our previous studies of regional air pollution transport (Manktelow et al., 2009). Volcanic $\mathrm{SO}_{2}$ is lofted into the free troposphere where the formed $\mathrm{H}_{2} \mathrm{SO}_{4}$ vapour causes rapid nucleation of new particles at low temperatures. These particles grow by coagulation and condensation of further vapour during long-range transport. Although the mass of sulphate is quite small far from the eruption, it is present in a large number of small particles that are very effective CCN. In Manktelow et al. (2009) we showed that Asian pollutant sulphur emissions are lofted higher into the free troposphere than other regional emissions and therefore have a high "CCN formation potential". A similar high CCN formation potential applies to an eruption like Laki.

Our model simulations also suggest that the impact of an equivalent wintertime eruption on upper tropospheric $\mathrm{CCN}$ is less than a summer eruption. The upper tropospheric zonal 3month mean $\mathrm{CCN}$ concentration is predicted to be only about one-third of that of a summertime eruption. However, a wintertime eruption is predicted to have a comparable or slightly larger effect on $\mathrm{CCN}$ concentrations in the boundary layer.

Our simulations also show that the Laki eruption can affect CCN concentrations in the Southern Hemisphere. At $20^{\circ} \mathrm{S}$, the summertime eruption increases $\mathrm{CCN}$ concentra- tions at the altitude of low level clouds by up to $35 \mathrm{~cm}^{-3}$ (factor 1.4). Although this is a small increase, the effect on cloud droplet concentrations and the radiative properties of marine stratocumulus clouds should be quantified in future studies.

Our results highlight the importance of using a global aerosol model treating microphysical processes such as nucleation and particle growth to CCN sizes when modelling the effects of volcanic eruptions. Our simulations indicate that both the microphysical processes and the chemical processes controlling particle concentrations are fundamentally different when compared to an unperturbed atmosphere. Moreover, processes are non-linear throughout the season thus the effects of a high-latitude eruption are strongly dependent on the season the eruption commences.

Using a global aerosol microphysics model such as GLOMAP-mode advances our understanding of how volcanoes influence natural background aerosol microphysical properties and $\mathrm{CCN}$ concentrations, and enables the impact on cloud droplet number (CDN) concentrations to be calculated based on a fully resolved aerosol size distribution. In contrast, most GCMs use simplified schemes to derive CDN concentrations (e.g., Lohmann and Feichter, 2005) which do not account for microphysical processes controlling CDN. The impact of a Laki-style eruption on CDN and the magnitude of the first aerosol indirect effect will be the subject of a future study.

Acknowledgements. AS is funded by a Leeds University Research Scholarship (URS). GWM received funding from the UK National Centre for Atmospheric Science (NCAS) and from research grants from the UK Natural Environment Research Council (NERC). TJB is funded by a NERC-UK SOLAS studentship.

Edited by: C. H. Song

\section{References}

Andreae, M. O.: Correlation between cloud condensation nuclei concentration and aerosol optical thickness in remote and polluted regions, Atmos. Chem. Phys., 9, 543-556, doi:10.5194/acp-9-543-2009, 2009.

Andres, R. J. and Kasgnoc, A. D.: A time-averaged inventory of subaerial volcanic sulfur emissions, J. Geophys. Res., 103, 25251-25262, 1998.

Breider, T. J., Chipperfield, M. P., Richards, N. A. D., Carslaw, K. S., Mann, G. W., and Spracklen, D. V.: Impact of $\mathrm{BrO}$ on dimethylsulfide in the remote marine boundary layer, Geophys. Res. Lett., 37, L02807, doi:10.1029/2009GL040868, 2010.

Chenet, A. L., Fluteau, F., and Courtillot, V.: Modelling massive sulphate aerosol pollution, following the large 1783 Laki basaltic eruption, Earth Planet. Sc. Lett., 236, 721-731, 2005.

Chipperfield, M. P.: New version of the TOMCAT/SLIMCAT offline chemical transport model: intercomparison of stratospheric tracer experiments, Q. J. Roy. Meteor. Soc., 132, 1179-1203, 2006. 
Clausen, H. B. and Hammer, C.: The Laki and Tambora eruptions as revealed in Greenland ice cores from 11 locations, Ann. Glaciol., 10, 16-22, 1988.

Courtillot, V.: New evidence for massive pollution and mortality in Europe in 1783-1784 may have bearing on global change and mass extinctions, C. R. Geosci., 337, 635-637, 2005.

Dentener, F., Kinne, S., Bond, T., Boucher, O., Cofala, J., Generoso, S., Ginoux, P., Gong, S., Hoelzemann, J. J., Ito, A., Marelli, L., Penner, J. E., Putaud, J.-P., Textor, C., Schulz, M., van der Werf, G. R., and Wilson, J.: Emissions of primary aerosol and precursor gases in the years 2000 and 1750 prescribed data-sets for AeroCom, Atmos. Chem. Phys., 6, 43214344, doi:10.5194/acp-6-4321-2006, 2006.

Fiacco, R. J., Thordarson, T., Germani, M. S., Self, S., Palais, J. M., Whitlow, S., and Grootes, P. M.: Atmospheric aerosol loading and transport due to the 1783-84 Laki eruption in Iceland, Interpreted from ash particles and acidity in the Gisp2 ice core, Quat. Res., 42, 231-240, 1994.

Gassó, S.: Satellite observations of the impact of weak volcanic activity on marine clouds, J. Geophys. Res., 113, D14S19, doi:10.1029/2007JD009106, 2008.

Gauci, V., Blake, S., Stevenson, D. S., and Highwood, E. J.: Halving of the northern wetland $\mathrm{CH}_{4}$ source by a large Icelandic volcanic eruption, J. Geophys. Res., 113, G00A11, doi:10.1029/2007JG000501, 2008.

Gong, S. L.: A parameterization of sea-salt aerosol source function for sub- and super-micron particles, Global Biogeochem. Cy., 17(4), 1097, doi:10.1029/2003GB002079, 2003.

Graf, H.-F.: Arctic radiation deficit and climate variability, Clim. Dynam., 7, 19-28, 1992.

Graf, H.-F., Feichter, J., and Langmann, B.: Volcanic sulfur emissions: estimates of source strength and its contribution to the global sulfate distribution, J. Geophys. Res., 102, 727-738, 1997.

Grattan, J.: Pollution and paradigms: lessons from Icelandic volcanism for continental flood basalt studies, Lithos, 79, 343-353, 2005.

Grattan, J., Durand, M., and Taylor, S.: Illness and elevated human mortality in Europe coincident with the Laki fissure eruption, in: Volcanic Degassing, edited by: Oppenheimer, C., Pyle, D. M., and Barclay, J., Geological Society, London, UK, Special Publications, 213, 401-414, 2003.

Halmer, M., Schmincke, H., and Graf, H.-F.: The annual volcanic gas input into the atmosphere, in particular into the stratosphere, a global data-set for the past 100 years, J. Volcanol. Geoth. Res., 115, 511-528, 2002.

Highwood, E.-J. and Stevenson, D. S.: Atmospheric impact of the 1783-1784 Laki Eruption: Part II Climatic effect of sulphate aerosol, Atmos. Chem. Phys., 3, 1177-1189, doi:10.5194/acp3-1177-2003, 2003.

Kekonen, T., Moore, J. C., Perämäki, P., and Martma, T.: The Icelandic Laki volcanic tephra layer in the Lomonosovfonna ice core, Svalbard, Polar Res., 24, 33-40, 2005.

Kettle, A. J. and Andreae, M. O.: Flux of dimethylsulfide from the oceans: a comparison of updated data sets and flux models, J. Geophys. Res., 105, 26793-26808, 2000.

Koch, D., Schmidt, G., and Field, C.: Sulfur, sea salt and radionuclide aerosols in GISS ModelE, J. Geophys. Res, 111, D06206, doi:10.1029/2004JD005550, 2006.

Korhonen, H., Carslaw, K. S., Spracklen, D. V., Ridley, D. A., and
Ström, J.: A global model study of processes controlling aerosol size distributions in the Arctic spring and summer, J. Geophys. Res., 113, D08211, doi:10.1029/2007JD009114, 2008.

Levine, J. G., Braesicke, P., Harris, N. R. P., Savage, N. H., and Pyle, J. A.: Pathways and timescales for troposphere-tostratosphere transport via the tropical tropopause layer and their relevance for very short lived substances, J. Geophys. Res.Atmos., 112, D04308, doi:10.1029/2005JD006940, 2007.

Levine, J. G., Braesicke, P., Harris, N. R. P., and Pyle, J. A.: Seasonal and inter-annual variations in troposphere-to-stratosphere transport from the tropical tropopause layer, Atmos. Chem. Phys., 8, 3689-3703, doi:10.5194/acp-8-3689-2008, 2008.

Lohmann, U. and Feichter, J.: Lohmann, U. and Feichter, J.: Global indirect aerosol effects: a review, Atmos. Chem. Phys., 5, 715737, doi:10.5194/acp-5-715-2005, 2005.

Manktelow, P. T., Mann, G. W., Carslaw, K. S., Spracklen, D. V., and Chipperfield, M. P.: Regional and global trends in sulfate aerosol since the 1980s, Geophys. Res. Lett., 34, L14803, doi:10.1029/2006GL028668, 2007.

Manktelow, P. T., Carslaw, K. S., Mann, G. W., and Spracklen, D. V.: Variable CCN formation potential of regional sulfur emissions, Atmos. Chem. Phys., 9, 3253-3259, doi:10.5194/acp-93253-2009, 2009.

Mann, G. W., Carslaw, K. S., Spracklen, D. V., Ridley, D. A., Manktelow, P. T., Chipperfield, M., Pickering, S. J., and Johnson, C. E.: Description and evaluation of GLOMAP-MODE: a modal global aerosol microphysics model for the UKCA composition-climate model, Geosci. Model Dev. Discuss., 3, 651-734, doi:10.5194/gmdd-3-651-2010, 2010.

Mather, T. A., Pyle, D. M., and Oppenheimer, C.: Tropospheric Volcanic Aerosol, in: Volcanism and the Earth's Atmosphere, Geophys. Monogr., American Geophysical Union (AGU), 139, 189-212, 2003.

Mather, T. A.: Volcanism and the atmosphere: the potential role of the atmosphere in unlocking the reactivity of volcanic emissions, Philos. T. Roy. Soc. A, 366, 4581-4595, 2008.

Mather, T. A., Tsanev, V. I., Pyle, D. M., McGonigle, A. J. S., Oppenheimer, C., and Allen, A. G.: Characterization and evolution of tropospheric plumes from Lascar and Villarrica volcanoes, Chile, J. Geophys. Res., 109, D21303, doi:10.1029/2004JD004934, 2004.

Mosley-Thompson, E., Mashiotta, T. A., and Thompson, L. G.: High resolution ice core records of late Holocene volcanism: current and future contributions from the Greenland PARCA cores, in: Volcanism and the Earth's Atmosphere, Geophys. Monogr., American Geophysical Union (AGU), 139, 153-164, 2003.

Niemeier, U., Timmreck, C., Graf, H.-F., Kinne, S., Rast, S., and Self, S.: Initial fate of fine ash and sulfur from large volcanic eruptions, Atmos. Chem. Phys., 9, 9043-9057, doi:10.5194/acp9-9043-2009, 2009.

Nightingale, P. D., Malin, G., Law, C. S., Watson, A. J., Liss, P. S., Liddicoat, M. I., Boutin, J., and Upstill-Goddard, R. C.: In situ evaluation of air-sea gas exchange - parameterizations using novel conservative and volatile tracers, Global Biogeochem. Cy., 14(1), 373-387, 2000.

Oman, L., Robock, A., Stenchikov, G. L., Thordarson, T., Koch, D., Shindell, D. T., and Gao, C.: Modeling the distribution of the volcanic aerosol cloud from the 1783-1784 Laki eruption, J. Geophys. Res., 111, D12209, doi:10.1029/2005JD006899, 2006a. 
Oman, L., Robock, A., Stenchikov, G. L., and Thordarson, T.: High-latitude eruptions cast shadow over the African monsoon and the flow of the Nile, Geophys. Res. Lett., 33, L18711, doi:10.1029/2006GL027665, 2006b.

Pham, M., Mueller, J. F., Brasseur, G. P., Granier, C., and Megie, G.: A three-dimensional study of the tropospheric sulfur cycle, J. Geophys. Res., 100(D12), 26061-26092, 1995.

Schmidt, G. A., Ruedy, R., Hansen, J. E., Aleinov, I., Bell, N., Bauer, M., Bauer, S., Cairns, B., Canuto, V., Cheng, Y., Del Genio, A., Faluvegi, G., Friend, A. D., Hall, T. M., Hu, Y. Y., Kelley, M., Kiang, N. Y., Koch, D., Lacis, A. A., Lerner, J., Lo, K. K., Miller, R. L., Nazarenko, L., Oinas, V., Perlwitz, J., Perlwitz, J., Rind, D., Romanou, A., Russell, G. L., Sato, M., Shindell, D. T., Stone, P. H., Sun, S., Tausnev, N., Thresher, D., and Yao, M. S.: Present-day atmospheric simulations using GISS ModelE: Comparison to in situ, satellite, and reanalysis data, J. Climate, 19, 153-192, 2006.

Spracklen, D. V., Pringle, K. J., Carslaw, K. S., Chipperfield, M. P., and Mann, G. W.: A global off-line model of size-resolved aerosol microphysics: II. Identification of key uncertainties, Atmos. Chem. Phys., 5, 3233-3250, doi:10.5194/acp-5-3233-2005, 2005a.

Spracklen, D. V., Pringle, K. J., Carslaw, K. S., Chipperfield, M. P., and Mann, G. W.: A global off-line model of size-resolved aerosol microphysics: II. Identification of key uncertainties, Atmos. Chem. Phys., 5, 3233-3250, doi:10.5194/acp-5-3233-2005, 2005b.

Highwood, E.-J. and Stevenson, D. S.: Atmospheric impact of the 1783-1784 Laki Eruption: Part II Climatic effect of sulphate aerosol, Atmos. Chem. Phys., 3, 1177-1189, doi:10.5194/acp3-1177-2003, 2003.

Stothers, R. B.: Major optical depth perturbations to the stratosphere from volcanic eruptions: pyrheliometric period, 18811960, J. Geophys. Res.-Atmos., 101, 3901-3920, 1996.

Textor, C., Schulz, M., Guibert, S., Kinne, S., Balkanski, Y., Bauer, S., Berntsen, T., Berglen, T., Boucher, O., Chin, M., Dentener, F., Diehl, T., Easter, R., Feichter, H., Fillmore, D., Ghan, S., Ginoux, P., Gong, S., Grini, A., Hendricks, J., Horowitz, L., Huang, P., Isaksen, I., Iversen, I., Kloster, S., Koch, D., Kirkevåg, A., Kristjansson, J. E., Krol, M., Lauer, A., Lamarque, J. F., Liu, X., Montanaro, V., Myhre, G., Penner, J., Pitari, G., Reddy, S., Seland, Ø., Stier, P., Takemura, T., and Tie, X.: Analysis and quantification of the diversities of aerosol life cycles within AeroCom, Atmos. Chem. Phys., 6, 1777-1813, doi:10.5194/acp-6-1777-2006, 2006.
Thordarson, T.: Volatile release and atmospheric effects of basaltic fissure eruptions, Ph.D. thesis, University of Hawaii, Honolulu, Hawaii, 1995.

Thordarson, Th. and Self, S.: Atmospheric and environmental effects of the 1783-1784 Laki eruption: A review and reassessment, J. Geophys. Res.-Atmos., 108(D1), 4011, doi:10.1029/2001JD002042, 2003.

Thordarson, T., Self, S., Oskarsson, N., and Hulsebosch, T.: Sulfur, chlorine, and fluorine degassing and atmospheric loading by the 1783-1784 AD Laki (Skaftar fires) eruption in Iceland, B. Volcanol., 58, 205-225, 1996.

Timmreck, C., Lorenz, S. J., Crowley, T. J., Kinne, S., Raddatz, T. J., Thomas, M. A., and Jungclaus, J. H.: Limited temperature response to the very large AD 1258 volcanic eruption, Geophys. Res. Lett., 36, L21708, doi:10.1029/2009GL040083, 2009.

Trigo, R., Vaquero, J., and Stothers, R.: Witnessing the impact of the 1783-1784 Laki eruption in the Southern Hemisphere, Climatic Change, online available at: http://www.springerlink.com/ content/0wk3765563711847/, 2009.

Turco, R. P., Toon, O. B., Whitten, R. C., Hamill, P., and Keesee, R. G.: The 1980 eruptions of Mount St. Helens: physical and chemical processes in the stratospheric clouds, J. Geophys. Res., 88, 5299-5319, 1983.

Zielinski, G. A., Mayewski, P. A., Meeker, L. D., Grönvold, K., Germani, M. S., Whitlow, S., Twickler, M. S., and Taylor, K.: Volcanic aerosol records and tephrochronology of the Summit, Greenland, ice cores, J. Geophys. Res., 102(C12), 26625-26640, 1997. 